\title{
Spatial and Seasonal Nutrient Trends in Manila Bay Aquaculture Farms
}

\author{
Opinion, April Grace R.*, Raña, Joan A., Perelonia, Karl Bryan S.,
} Abendanio, Camille C., and Cambia, Flordeliza D.

Fisheries Post Harvest Research and Development Division,

National Fisheries Research and Development Institute, Quezon City, Philippines 1103

\begin{abstract}
Sampling was done in duplicates during dry (May 2014 and February 2015) and wet season (September 2014 and November 2014) following the blocking scheme for the nutrient trends. As for the nutrient loading, water samples were collected in three ponds after flooding (water intrusion) and prior to draining (water release). Colorimetric analyses by UV-Vis Spectroscopy following the US EPA standard methods were used to determine the samples' nutrient levels specifically, ammonia, nitrate, nitrite, and phosphorus. Results showed that ammonia had the highest levels followed by phosphorus, nitrate, and nitrite. Geographically, higher concentration of nitrogen and phosphorus were observed in Eastern Bulacan aquaculture farms, which is attributed to the farmers' disregard of the important pond preparation activities. Varying seasonal trends were noted among nutrient species due to the different reactions of each analyte under changing climatic conditions. Nutrient levels in sediments were several folds higher than that in the water column. Results of correlation analyses of nutrients in water and sediments showed: a) a good correlation for phosphorus, b) weak correlation for ammonia, and c) no correlation for nitrites and nitrates, implying that sediments maybe a possible contributor of phosphorus and ammonia in water but not nitrite and nitrate. Ammonia and TKN were significantly higher during the flooding suggesting that water coming in to the pond already contains high levels of said nutrients possibly due to higher organic load. Conversely, nitrite and nitrate levels were significantly higher during the draining suggesting transformation of ammonia into these less toxic substances by nitrifying bacteria.
\end{abstract}

Keywords: aquaculture, nitrogen, phosphorus, Manila Bay 


\section{INTRODUCTION}

Nutrients, such as nitrogen and phosphorus, are indispensable elements in growing all forms of aquatic life, including algae, fish, crustaceans, mollusks, microbes and other organisms. They are constituents of various coenzymes, nucleic acids, amino acids, lipids, ATP (energy carrier) and some macromolecules that are important in the biological processes of different culture organisms (Hardy \& Gatlin, 2002; Olsen et al, 2008). Phosphorus is also a structural component of fish bones, teeth, scales and skin (Chow \& Schell, 1980; Olsen, 2008). Moreover, these nutrients increase primary productivity of the aquatic culture environment which eventually increases the total productivity as it forms the base of the food chain and improves the water quality by the augmented production of dissolved oxygen in water (Conte, 2000; Golez, 2009; Tucker \& Hargreaves, 2012).

Despite their essentiality, nutrients are often present in short supply (Havens \& Frazer, 2012). In order to increase aquaculture production to support the food demand of the growing human population, phosphorus and nitrogen must be applied in the culture system through fertilization and feeding. Fertilizers used in aquaculture may either be organic (e.g. animal manure, molasses from sugar cane, composted vegetation and different by-products of other industries) or inorganic fertilizer, which is synthetically produced with concentrated and known amount of nitrogen and phosphorus (Golez, 2009). Feed ingredients from animal or fish by-products also contain relatively high levels of phosphorus and nitrogen coming from bones and protein component of these ingredients (Hardy \& Gatlin, 2002). Aside from the inputs, the culture species itself may release such nutrients that are not absorbed by the body through faeces and other wastes (Science for Envi- ronment Policy, 2015; Hardy \& Gatlin, 2002).

These nutrients occur in several forms in water: nitrogen can be in the form of soluble organic $\mathrm{N}$, ammonium $\left(\mathrm{NH}_{4}-\mathrm{N}\right)$, ammonia $\left(\mathrm{NH}_{3}-\mathrm{N}\right)$, nitrate $\left(\mathrm{NO}_{3}-\mathrm{N}\right)$ and nitrite $\left(\mathrm{NO}_{2}-\mathrm{N}\right)$, while phosphorus exists as orthophosphate and undifferentiated organic phosphates (Ongley, 1996; Kutty, 1986; Golez, 2009).

However, along with the global increase in fish production from aquaculture, several environmental concerns regarding the nutrients released by fish farms have been raised. In fact, the United States Environmental Protection Agency (US-EPA) identified nutrients as a significant problem contributing to water pollution (MPCA, 2008). Excessive nitrogen and phosphorus in water (from different sources including aquaculture) result in eutrophication (Smith et al, 2006), which is the leading cause of water quality impairment around the world (Diaz et al, 2012). Eutrophication leads to series of adverse impacts on aquatic ecosystems. Perhaps the most commonly observed is the accumulation of nuisance levels of algal biomass (Smith et al, 1999) which eventually reduce light penetration and lead to a loss of submerged aquatic vegetation, including seagrass beds and coral reefs (Carpenter et al, 1999; Diaz et al, 2012). The imbalance of nutrient ratios may also lead to a shift in phytoplankton species composition, which also alters the aquatic food webs creating conditions favorable to the dominance of toxic algal blooms (Smith et al, 1999; Smith et al, 2006; Diaz et al, 2012). Worse, the decomposition process of these algal blooms require dissolved oxygen which results in oxygen shortages in the water thus causing massive fish kills (Carpenter et al, 1998).

Aside from its impact to the environ- 
ment, an excessive amount of nutrients also adversely affects the culture organisms. A slight increase in ammonia concentration, for example, can already impair fish growth rate and morphological development, while extreme levels may cause severe convulsions, coma and death (Mueller \& Helsel, 1996). Excess nitrite, on the other hand, can lead to brown blood disease or a condition wherein the oxygen carrier hemoglobin in the blood is converted to the non-oxygen carrier methemoglobin when combined with nitrite which eventually leads to fish suffocation even at sufficient oxygen (Kroupova, 2005; Durborow et al, 1997). Too much nitrate can also cause hypoxia (depletion of dissolved oxygen) and can become toxic to warm-blooded animals under certain conditions (US-EPA, 2012).

Manila bay is a semi-closed bay system populated with approximately 20 million people (PSA, 2010) along its coastal provinces (Metro Manila, Bulacan, Bataan, Pampanga and Cavite). The bay is also used for various purposes including aquaculture which accounts for as much as $59 \%$ of its total economic value (PEAMSEA, 2006). According to Perez et al (1999), fish, fish pens and shellfish pens proliferate in the provinces surrounding the bay such as Bulacan, Bataan Pampanga, Cavite, and the northern Metro Manila coastlines, covering an aquaculture area of almost 60,000 ha.

The bay has been plagued with several environmental problems including increased organic and nutrient loading coming from several sources like aquaculture, which eventually resulted to episodic hypoxic conditions of its water, intermittent fish kills of cultivated and wild stocks, increased incidence of toxic and nuisance algal blooms and higher suspended material in the water column (Jacinto et al, 2008; Reichardt, 2007). Furthermore, Chang et al (2009), reported that Manila Bay is highly eutrophicated with organic nutrients such as nitrogen. Phosphate in the wa- ter column in all areas of the Bay has also exceeded the recognized marine water quality criterion of a healthy ecosystem of 0.015 $\mathrm{mg} / \mathrm{L}$ by almost twofold (PEMSEA, 2006).

It has been hypothesized that the existence of different aquaculture activities along the bay is one of the contributors to water quality deterioration in the area. A review of aquaculture practices of farmers revealed that proper guidelines in good aquaculture practices is not followed. Estimation of nutrient levels in aquaculture farms as well as the nutrient loading in Manila Bay are essential in the assessment of the possible pollutants coming from various aquaculture activities. Therefore, the main purpose of this study is to establish baseline data on the spatial and seasonal levels of nutrients in aquaculture ponds, river streams, fish pens, and coastal areas; and to determine whether effluents from the aquaculture farms significantly contribute to nutrient pollution in the river and eventually out into Manila Bay.

\section{Methodology}

\section{Sampling Sites and Collection of Samples}

\section{NUTRIENT TRENDS}

Identification and standardization of sampling sites were described in the methods section of Chapter 2 in this publication.

Forty nine (49) pre-identified aquaculture farms and coastal areas were sampled twice for each season - May 2014 and February 2015 for the dry season and September 2014 and November 2015 for the wet season. As for the sediments, samples were collected only once for each season - May 2014 for the dry season and September 2014 for the wet season. River tributaries/water sources of 
the aquaculture farms were also sampled for comparison.

Water samples of approximately one (1) liter were collected for each analysis (nitrogen and phosphorus) while one hundred (100) grams of sediments were taken for the study. Manual grab sampling using intermediate container was the method used for collecting water and sediments (DENR-EMB, 2008).

Storage and preservation of the samples were done following the methods described by the US-EPA (Industrial Waste Resource Guidelines, 2009). All samples were analyzed within the specified holding time to avoid microbial buildup and chemical deterioration of a specific analyte.

\section{NUTRIENT LOADING}

Three fish ponds in Capitangan, Abucay, Bataan were sampled for the project. The ponds were empty at the beginning of the study to make sure nutrient concentrations in each step of the rearing period can be determined. Figure 3.1 shows the sampling site for the study.

Water samples of approximately one (1) liter were collected subsequent to water intrusion and prior to water discharge. Samples were collected in composite from three different points in the pond - near the water intrusion gate, at the middle, and at the end.

Storage and preservation of the samples were done following the methods described by the US-EPA (Industrial Waste Resource Guidelines, 2009). All samples were analyzed within the specified holding time to avoid microbial buildup and chemical deterioration of a specific analyte.

Water quality parameters such as $\mathrm{pH}$, dissolved oxygen, temperature, and salini- ty were also measured using HORIBA U-50 multi-parameter water quality meter in each of the sampling points water samples were collected. Interview was also conducted every sample collection to determine the input of the farmers in the pond - feeds, fertilizers, and other chemicals.

\section{Method of Analysis}

Total nitrogen and orthophosphate contents were analyzed using the Colorimetric by UV-Vis Spectroscopy following the standard methods of the US Environmental Protection Agency (Method numbers: 350.2, 351.3, 352.1, 354.1, and 365.2) and AOAC Official Methods of Analysis for water and sediments. The method detects total nitrogen and phosphorus with ranges 0.1 to $10 \mathrm{mg} \mathrm{N} / \mathrm{L}$ and 0.02 to $2 \mathrm{mg} \mathrm{P} / \mathrm{L}$, respectively.

Nitrogen and phosphorus concentrations were calculated from the external standard calibration. Total nitrogen was reported as the sum of nitrate $\left(\mathrm{NO}_{3}-\mathrm{N}\right)$, nitrite $\left(\mathrm{NO}_{2}-\mathrm{N}\right)$, ammonia $\left(\mathrm{NH}_{3}-\mathrm{N}\right)$, and organic nitrogen while total orthophosphate as the sum of dissolved and suspended orthophosphates $\left(\mathrm{PO}_{4}-\mathrm{P}\right)$. Minimum internal quality control schemes such as method/reagent blanks, recovery of fortified samples, and mid standards were applied during the analysis to ensure quality of analytical test results.

\section{$\underline{\text { Statistical Analysis }}$}

\section{NUTRIENT TRENDS}

Nutrient levels among blocks all throughout the sampling months were compared using one-way ANOVA while nutrient levels between the ponds and their water sources were compared using t-test. One-way ANOVA was also used to compare the nutrient concentrations among the sampling months. 


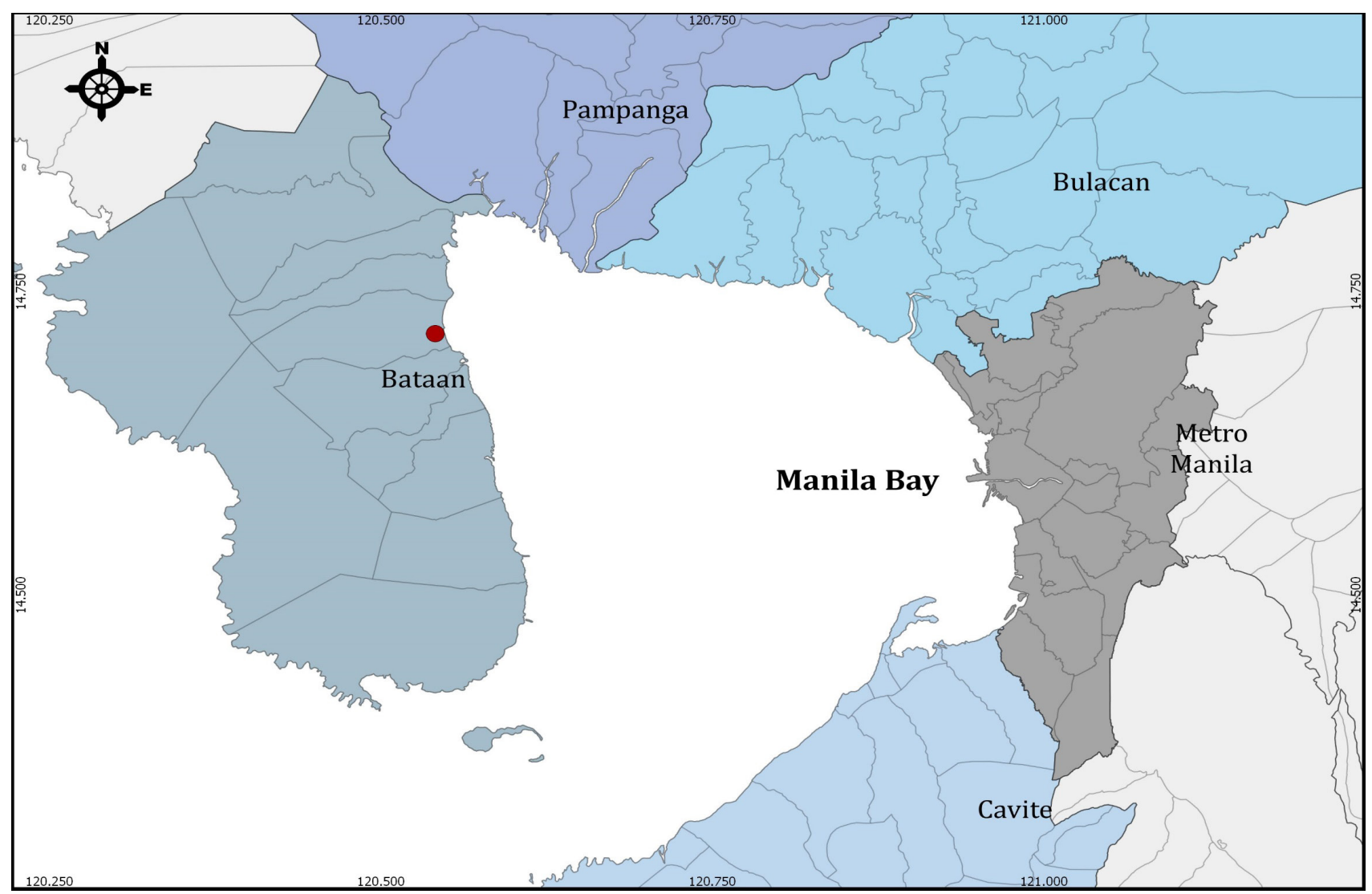

Figure 3.1. Location of sampling sites for nutrient loading.

Due to the absence of replicates, cluster analysis was used to compare the nutrient levels in each site within a block. Cluster analysis determines the group that are homogeneous in terms of several variables that characterize it, in this case, these are the nutrients. Clustering within each block was done for the months of May 2014, September 2014, November 2014, and February 2015 in the ponds and water sources.

\section{NUTRIENT LOADING}

Due to the limited number of cooperators, sampling periodswillserveasreplicatesfor each pond. A paired t-test comparing nutrient concentrations subsequent to water intrusion and prior to water discharge will be employed to determine whether the pond contributes significantly to the nutrient level in the river.

\section{Results}

\section{Nutrient Level in Water Source, Coastal} Area/Fish pens, and ponds

Levels of ammonia, nitrite, nitrate and phosphorus varied widely in relation to water source, coastal areas (shellfish growing areas), and fish ponds in the different blocks. Ammonia levels, which ranged from 0.0781 to $23.0909 \mu \mathrm{g} / \mathrm{ml}$, were found higher compared to the other nutrients. In the case of nitrite, concentrations were relatively lower than other nutrients as it only ranged from 0 to $0.1290 \mu \mathrm{g} / \mathrm{ml}$. Nitrate, on the other hand, were observed to be relatively higher than nitrite but relatively lower than ammonia, which ranged from 0 to $0.8183 \mu \mathrm{g} /$ $\mathrm{ml}$. As for the total phosphorus, the concentration ranged from 0.0080 to $3.7969 \mu \mathrm{g} / \mathrm{ml}$. 
In order to assess the extent of nutrient runoff into the bay, an empirical model that provides an estimate of pollution load will be based on the long term measurements of the concentrations of total nitrogen and phosphate in both pond and water source. When the concentration of nutrient in aquaculture pond is higher than its water source (river), then it is assumed that fish ponds are a source of nutrient overload in the bay. On the other hand, when the concentration of nutrient in water source is higher than the pond water, then the loading comes mainly from the upstream or the source itself.

\section{AMMONIA}

Ammonia levels during the dry and wet seasons in the coastal areas, fishponds, and water sources in the different blocks are shown in Figures 3.2a to 3.2d. Concentrations varied widely among the sampling sites in the different blocks. Ammonia levels of aquafarms (fishponds and coastal areas) in Eastern Bulacan, which ranged from $0.3911 \mu \mathrm{g} / \mathrm{ml}$ to $3.7455 \mu \mathrm{g} / \mathrm{ml}$, with the extremes in February 2015 and May 2014, respectively, were significantly higher $(\mathrm{p}<0.01)$ than other blocks all throughout the sampling months. Concentrations of ammonia in Cavite, Southern Bataan and Pampanga were comparable and significantly lower $(p<0.01)$ than those in Eastern Bulacan. Ammonia levels in Cavite and Pampanga, on the other hand, ranged from $0.0781 \mu \mathrm{g} / \mathrm{ml}$ to $1.7933 \mu \mathrm{g} / \mathrm{ml}$ and $0.2040 \mu \mathrm{g} /$ $\mathrm{ml}$ to $1.1768 \mu \mathrm{g} / \mathrm{ml}$, respectively, with extremes observed in February 2015 and May 2014. Southern Bataan ammonia ranged from $0.2310 \mu \mathrm{g} / \mathrm{ml}$ (September 2014) to $1.3419 \mu \mathrm{g} /$ $\mathrm{ml}$ (November 2014). In Northern Bataan and Western Bulacan, significantly lower $(p<0.01)$ ammonia levels than those in the blocks mentioned above were found, which ranged from $0.1340 \mu \mathrm{g} / \mathrm{ml}$ (February 2015) to $1.4780 \mu \mathrm{g} / \mathrm{ml}$

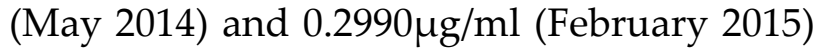
to $1.1620 \mu \mathrm{g} / \mathrm{ml}$ (September 2014), respectively.
Ammonia concentration in the water sources, which ranged from 0.1493 to $21.4217 \mu \mathrm{g} / \mathrm{ml}$ with the highest level obtained in Cavite during the February 2015 sampling, showed no significant difference $(p>0.05)$ when statistically compared to the fishponds ammonia levels.

\section{NITRITE}

Figures 3.3a to $3.3 \mathrm{~d}$ show the levels of nitrites in the different blocks during the sampling months. Comparing the nitrite levels of aquafarms in the different blocks, it was noted that Eastern Bulacan and Cavite samples have significantly higher concentration $(p<0.05)$ than those collected from the other blocks. The levels ranged from 0 to $0.1203 \mu \mathrm{g} / \mathrm{ml}$ and 0.0006 to $0.1290 \mu \mathrm{g} / \mathrm{ml}$, respectively, with maximum values noted in November 2014. Nitrite levels in Western Bulacan followed, which ranged from 0 to $0.0435 \mu \mathrm{g} / \mathrm{ml}$ peaking in November 2014. Pampanga, Northern Bataan and Southern Bataan nitrite levels were found comparable and significantly lower $(p<0.05)$ than the other blocks. In Northern Bataan, nitrite ranged from 0.0014 to $0.0526 \mu \mathrm{g} / \mathrm{ml}$ with peak observed in May 2014. Nitrite levels in Pampanga were almost the same as in Northern Bataan, which is 0.0014 to $0.0525 \mu \mathrm{g} / \mathrm{ml}$, with the highest value observed in February 2015. Southern Bataan, on the other hand, ranged from 0 to $0.0280 \mu \mathrm{g} / \mathrm{ml}$ (May 2014).

Similar to ammonia, nitrite levels in water source, which ranged from 0 to $0.1132 \mu \mathrm{g} / \mathrm{ml}$ with maximum value noted during September 2014 in Cavite, showed no significant difference $(p>0.05)$ when statistically compared to the nitrite concentration of fishponds.

\section{NITRATE}

Figures $3.4 \mathrm{a}$ to $3.4 \mathrm{~d}$ show the nitrate levels of aquafarms in different blocks. Ni- 


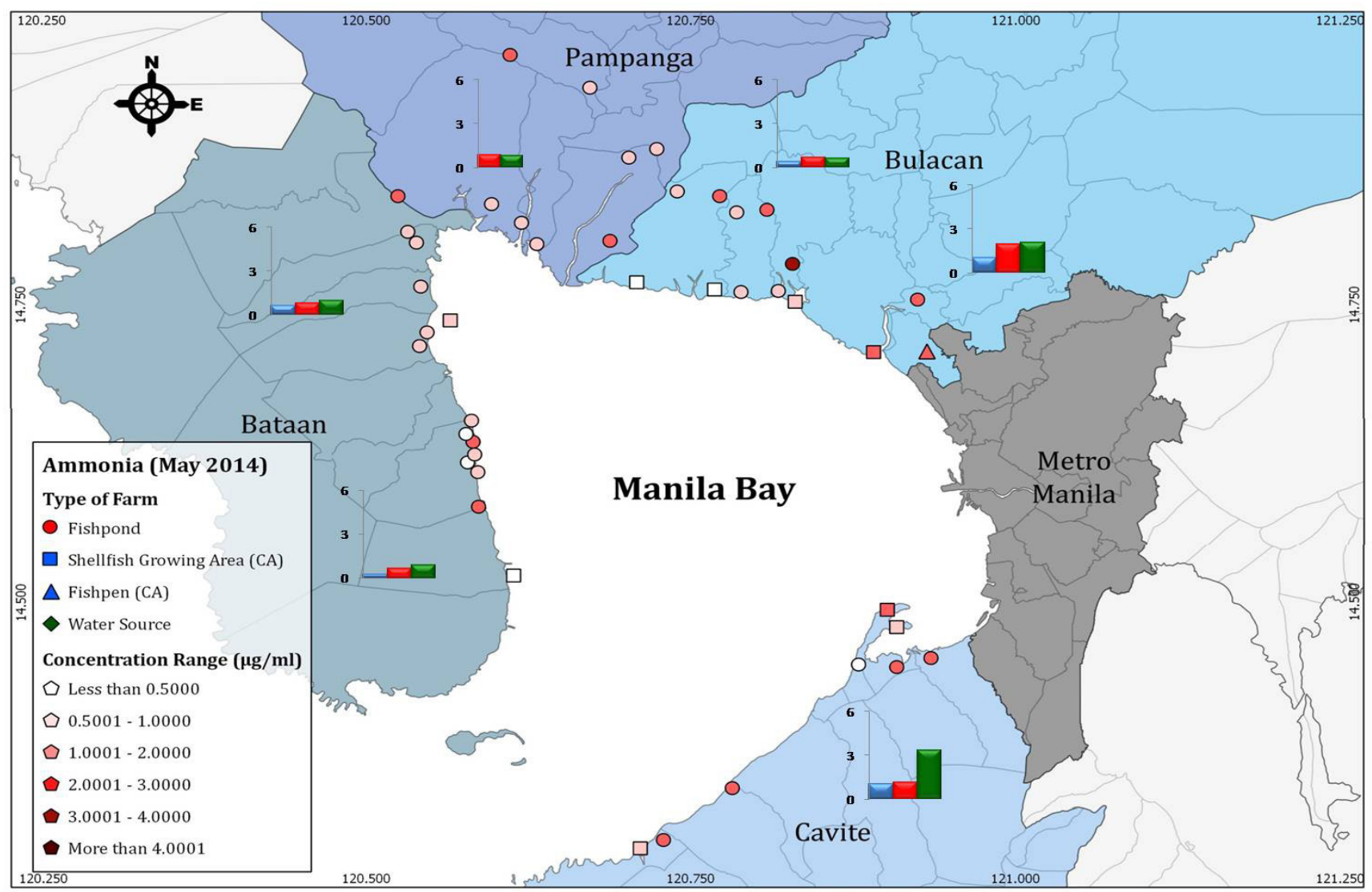

Figure 3.2a. Levels of ammonia in coastal areas/fish pens, ponds, and water sources in May 2014.

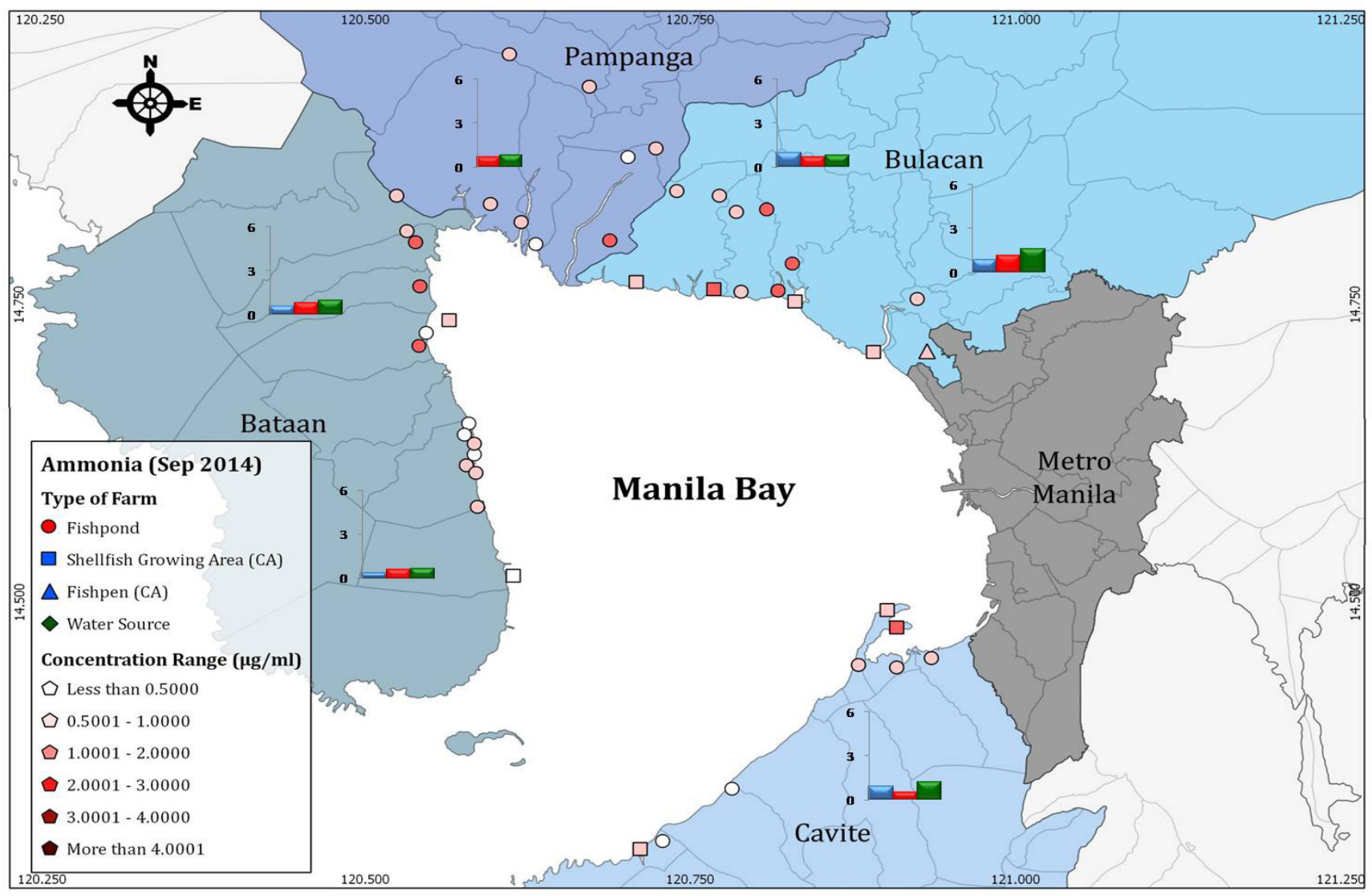

Figure 3.2b. Levels of ammonia in coastal areas/fish pens, ponds, and water sources in September 2014. 


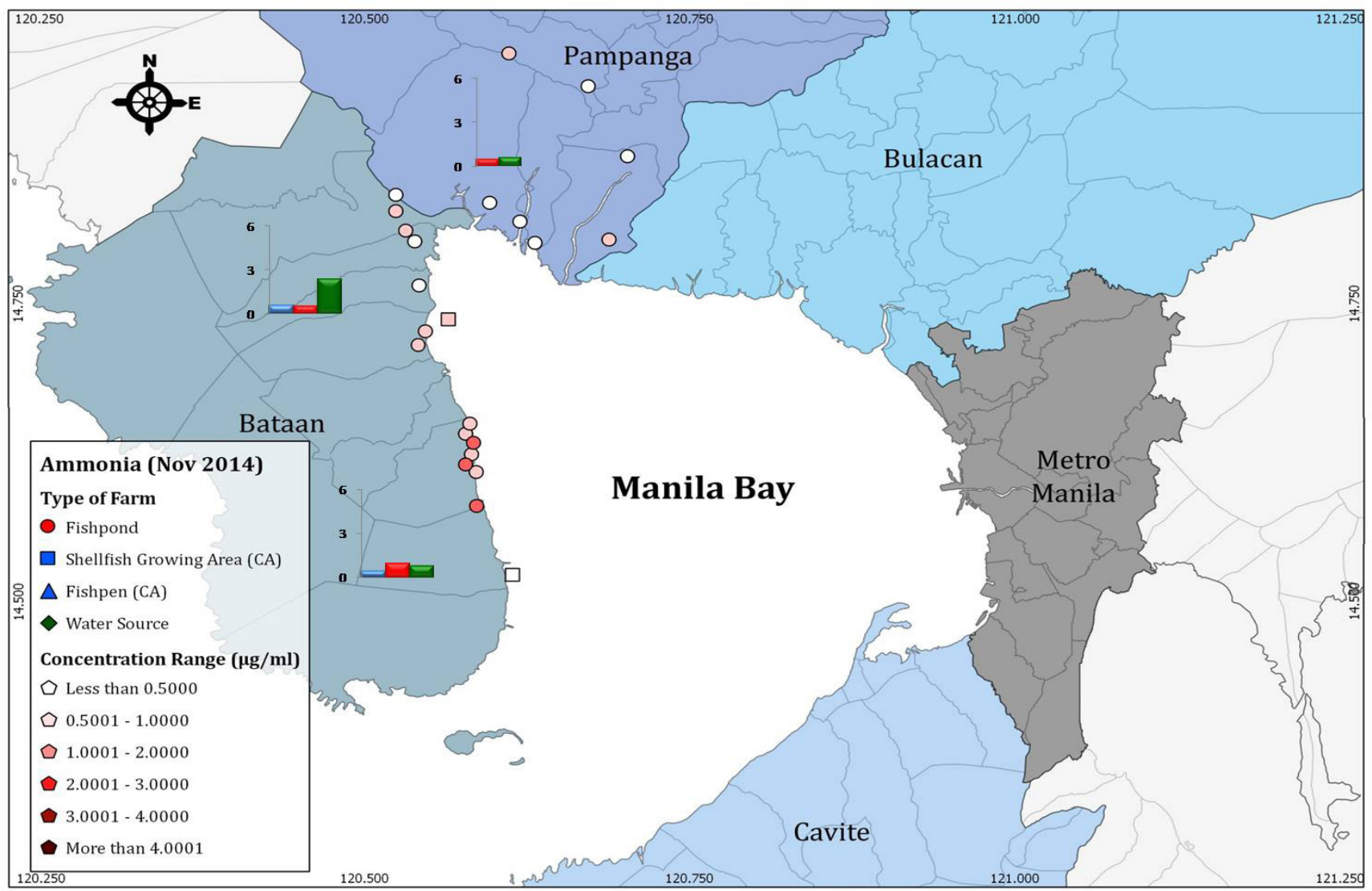

Figure 3.2c. Levels of ammonia in coastal areas/fish pens, ponds, and water sources in November 2014.

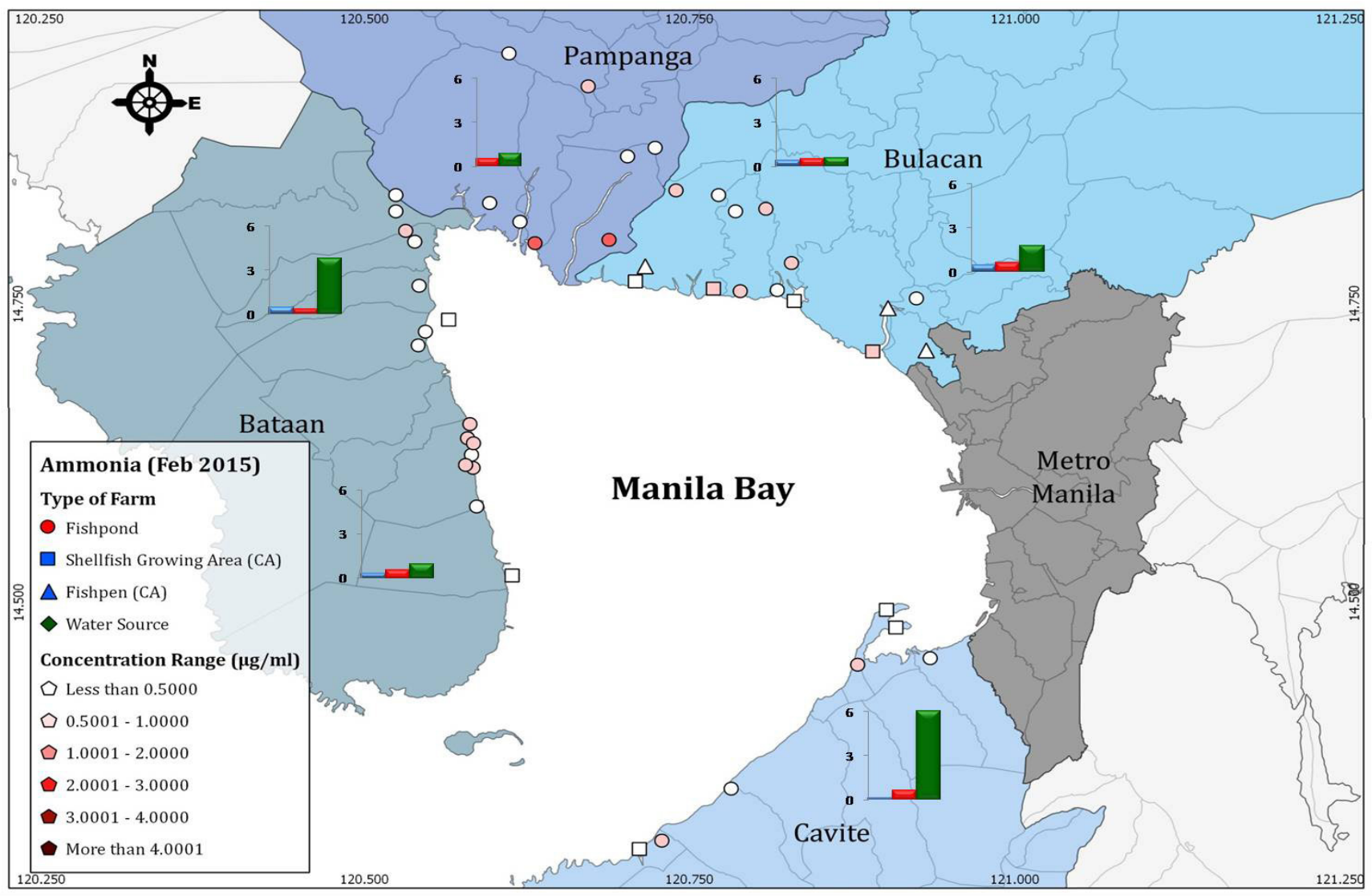

Figure 3.2d. Levels of ammonia in coastal areas/fish pens, ponds, and water sources in February 2015. 


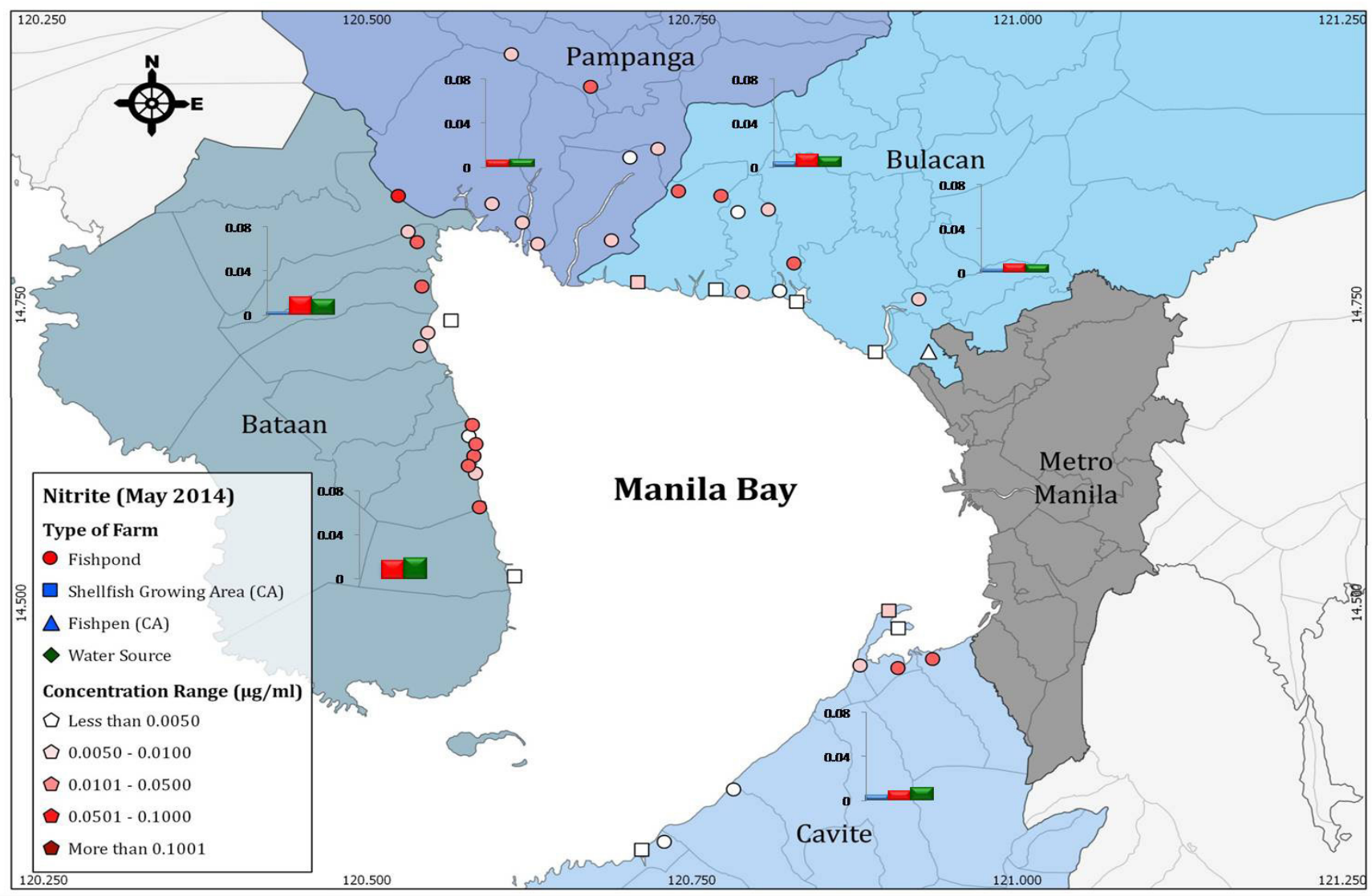

Figure 3.3a. Levels of nitrite in coastal areas/fish pens, ponds, and water sources in May 2014.

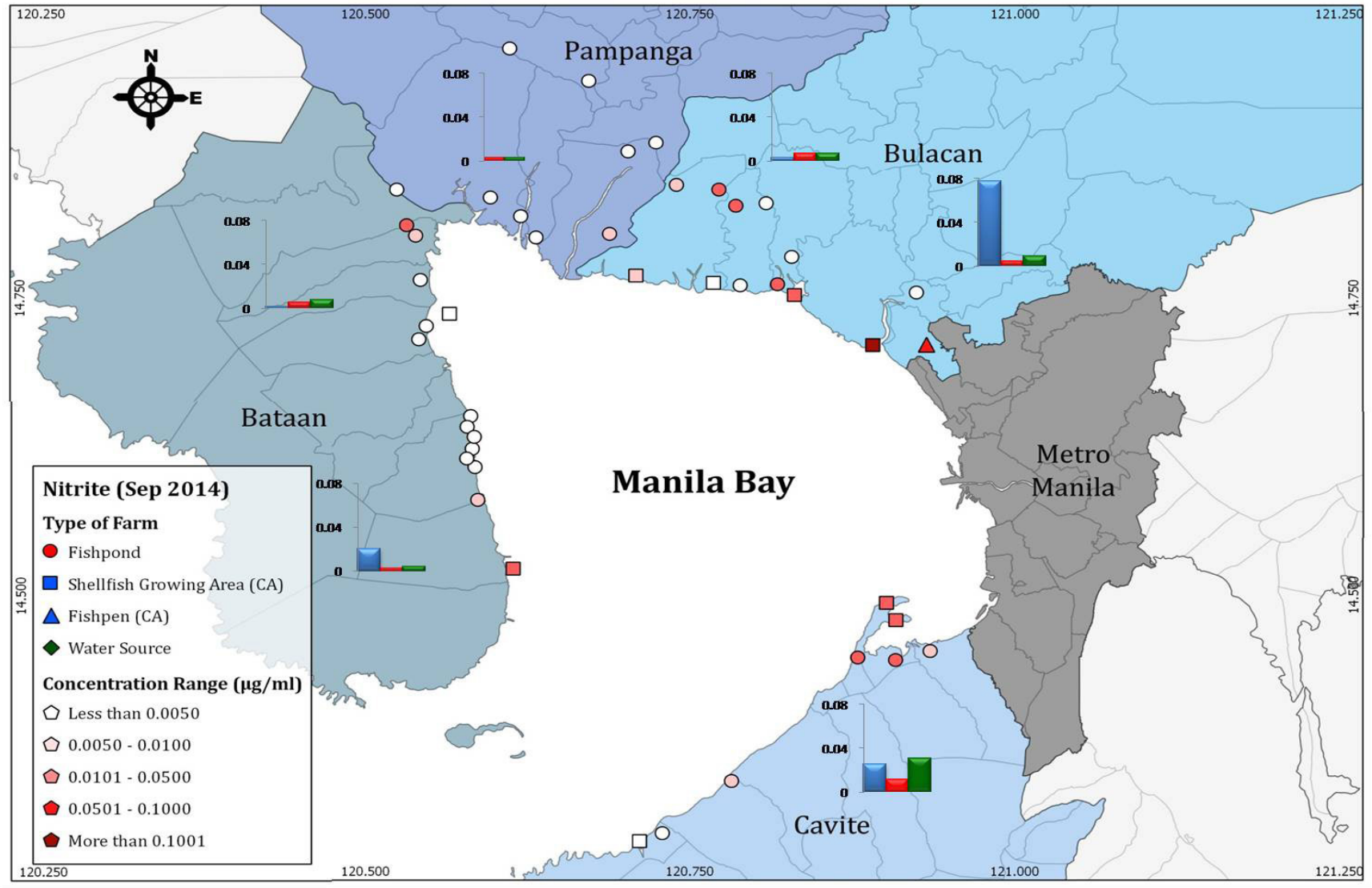

Figure 3.3b. Levels of nitrite in coastal areas/fish pens, ponds, and water sources in September 2014. 


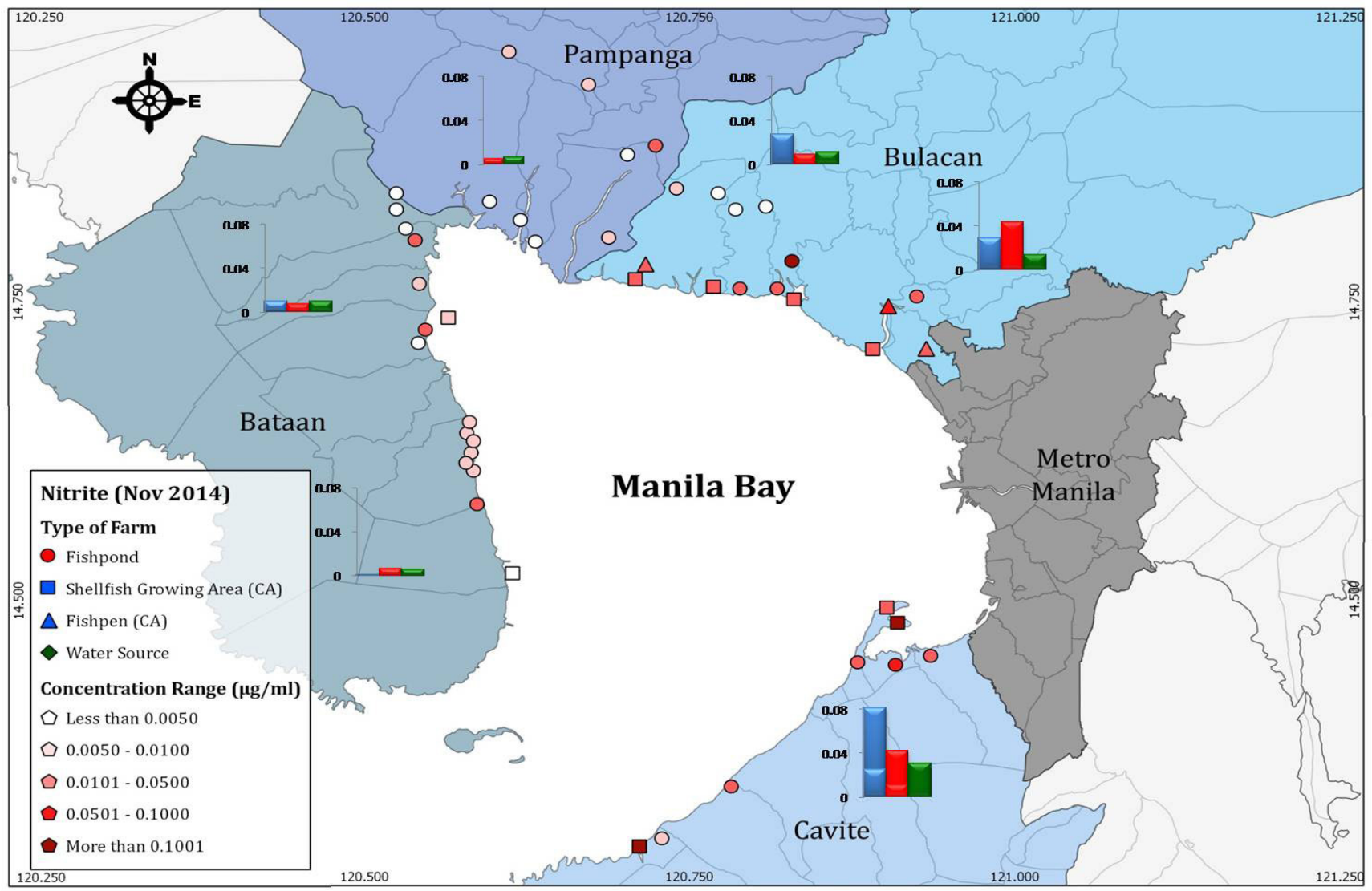

Figure 3.3c. Levels of nitrite in coastal areas/fish pens, ponds, and water sources in November 2014.

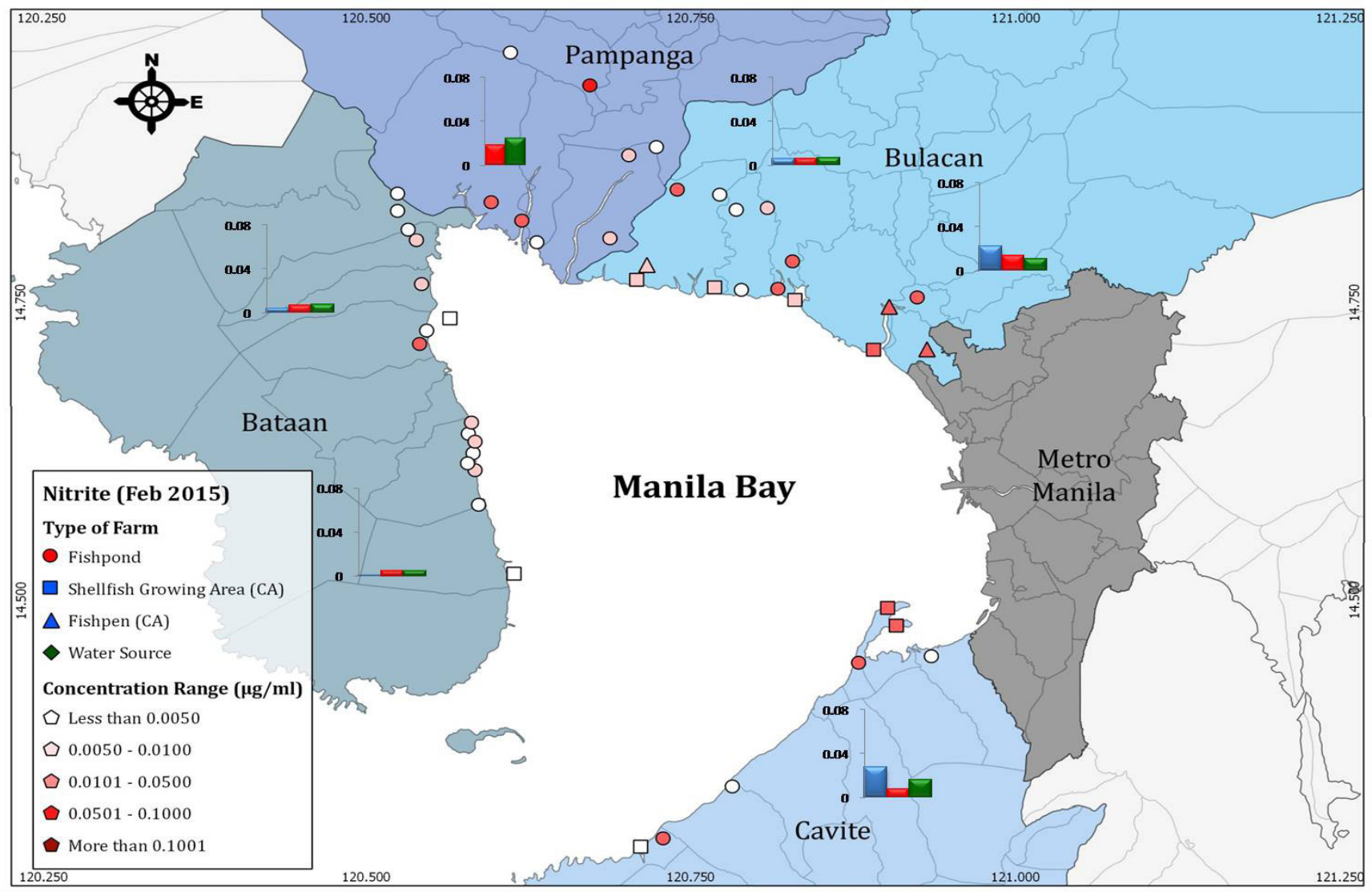

Figure 3.3d. Levels of nitrite in coastal areas/fish pens, ponds, and water sources in February 2015. 
trate concentration of aquafarms in Cavite had significantly higher $(\mathrm{p}<0.01)$ concentrations, which ranged from 0.0203 to $0.4459 \mu \mathrm{g} /$ $\mathrm{ml}$, with maximum value in the coastal area (November 2014). Nitrate levels in Pampanga, Northern Bataan, Eastern Bulacan, and Western Bulacan were comparable, with the highest recorded value at $0.2943 \mu \mathrm{g} / \mathrm{ml}$ (September 2014), $0.2837 \mu \mathrm{g} / \mathrm{ml}$ (February 2015), 0.2752 $\mu \mathrm{g} / \mathrm{ml}$ (September 2014), and $0.2303 \mu \mathrm{g} / \mathrm{ml}$ (September 2014), respectively. Aquafarms in Southern Bataan have relatively lower levels of nitrate, which ranged from 0 to $0.1632 \mu \mathrm{g} /$ $\mathrm{ml}$, with extremes noted in November 2014.

It was further observed that levels of nitrate in the water source, which ranged from 0 to $0.8183 \mu \mathrm{g} / \mathrm{ml}$ with maximum value in Cavite during September 2014, were relatively higher compared than those noted in fishponds. However, results of statistical analyses showed that the difference is only significant $(\mathrm{p}<0.05)$ in Southern Bataan in September 2014 and February 2015.

\section{PHOSPHORUS}

Seasonal levels of phosphorus in aquafarms are shown in Figures 3.5a to 3.5d. Phosphorus in Eastern Bulacan exhibited significantly higher $(\mathrm{p}<0.01)$ concentrations compared to the other blocks with a range of 0.0257 to $2.0116 \mu \mathrm{g} / \mathrm{ml}$ with peak in May 2014 . Pampanga phosphorus levels, which ranged from 0.1093 to $1.3635 \mu \mathrm{g} / \mathrm{ml}$ and with extremes noted in November 2014 and February 2015, were secondary to that of Eastern Bulacan. Cavite and Northern Bataan had nearly similar levels ranging from 0.0307 to 0.8200 $\mu \mathrm{g} / \mathrm{ml}$ and 0.0089 to $0.7605 \mu \mathrm{g} / \mathrm{ml}$, respectively, their peaks were in November 2014 and February 2015, respectively. Western Bulacan phosphorus levels had a range of 0.0213 (September 2014) to $0.4462 \mu \mathrm{g} / \mathrm{ml}$ (February
2014), while Southern Bataan, from 0.0080 (May 2014) to $0.3758 \mu \mathrm{g} / \mathrm{ml}$ (September 2014).

Phosphorus in the water sources ranged from 0.0222 to $3.7969 \mu \mathrm{g} / \mathrm{ml}$, peaking at Cavite in February 2015. Statistical analysis results showed that water source were significantly lower $(\mathrm{p}<0.05)$ than that in the fishponds in Northern Bataan (November 2014) and Southern Bataan (February 2015).

\section{SEASONAL VARIATION}

Seasonal variation in the nutrient levels of aquafarms in the different provinces is shown in Figure 3.6. Overall, ammonia concentration decreased from May 2014 (0.1797 to $3.7455 \mu \mathrm{g} / \mathrm{ml}$ ) to Feb 2015 (0.0781 to 1.1529 $\mu \mathrm{g} / \mathrm{ml})$. Nitrite levels were highest in November 2014 with a range of 0.0018 to $0.1290 \mu \mathrm{g} /$ $\mathrm{ml}$, and lowest in February with a range of $0.0011-0.0525 \mu \mathrm{g} / \mathrm{ml}$.

In the case of nitrate, levels were found lowest in May 2014 (range of $0-0.1390 \mu \mathrm{g} / \mathrm{ml}$ ) and highest in February 2015 (range of 0.0028 $-0.2932 \mu \mathrm{g} / \mathrm{ml}$ ). Seasonal change in phosphorus concentration was relatively insignificant. However, comparing the sampling months, phosphorus tended to be highest in May 2014, ranging from $0.0080-2.0116 \mu \mathrm{g} / \mathrm{ml}$, and lowest in November 2014, ranging from 0.0121 to $1.3483 \mu \mathrm{g} / \mathrm{ml}$.

\section{Nutrients in Sediments}

Nutrient levels in sediments in May and September 2014 are shown in Figures 3.7 to 3.10. Ammonia levels in sediments (range of $26.38-311.18 \mu \mathrm{g} / \mathrm{g}$ ), were found higher compared to the other nutrients. Next to ammonia is nitrate (range of $1.51-220.28 \mu \mathrm{g} / \mathrm{g}$ ). Total phosphorus and nitrite had the least concentrations which ranged from 0.27 to $47.64 \mu \mathrm{g} / \mathrm{g}$ 


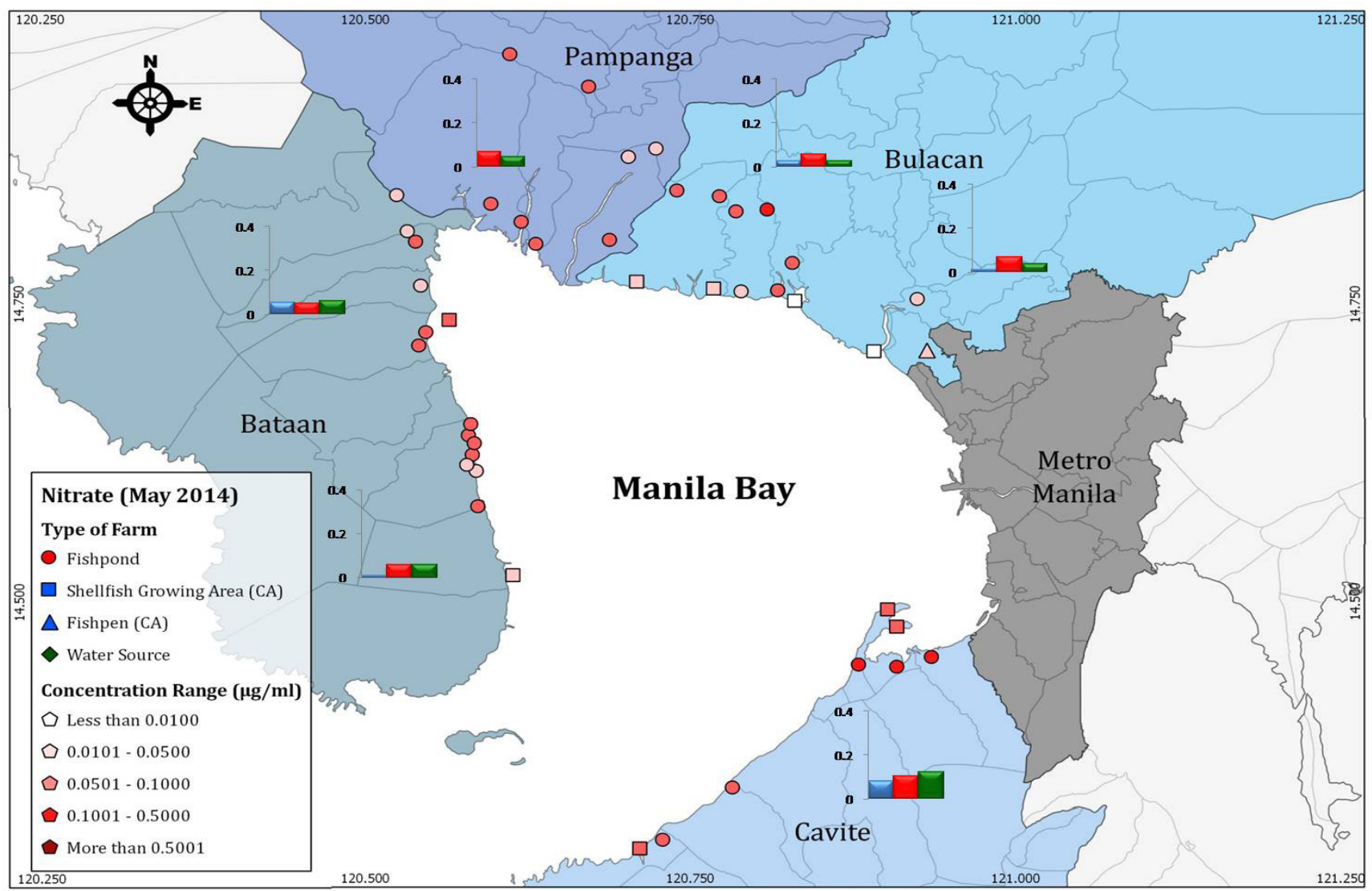

Figure 3.4a. Levels of nitrate in coastal areas/fish pens, ponds, and water sources in May 2014.

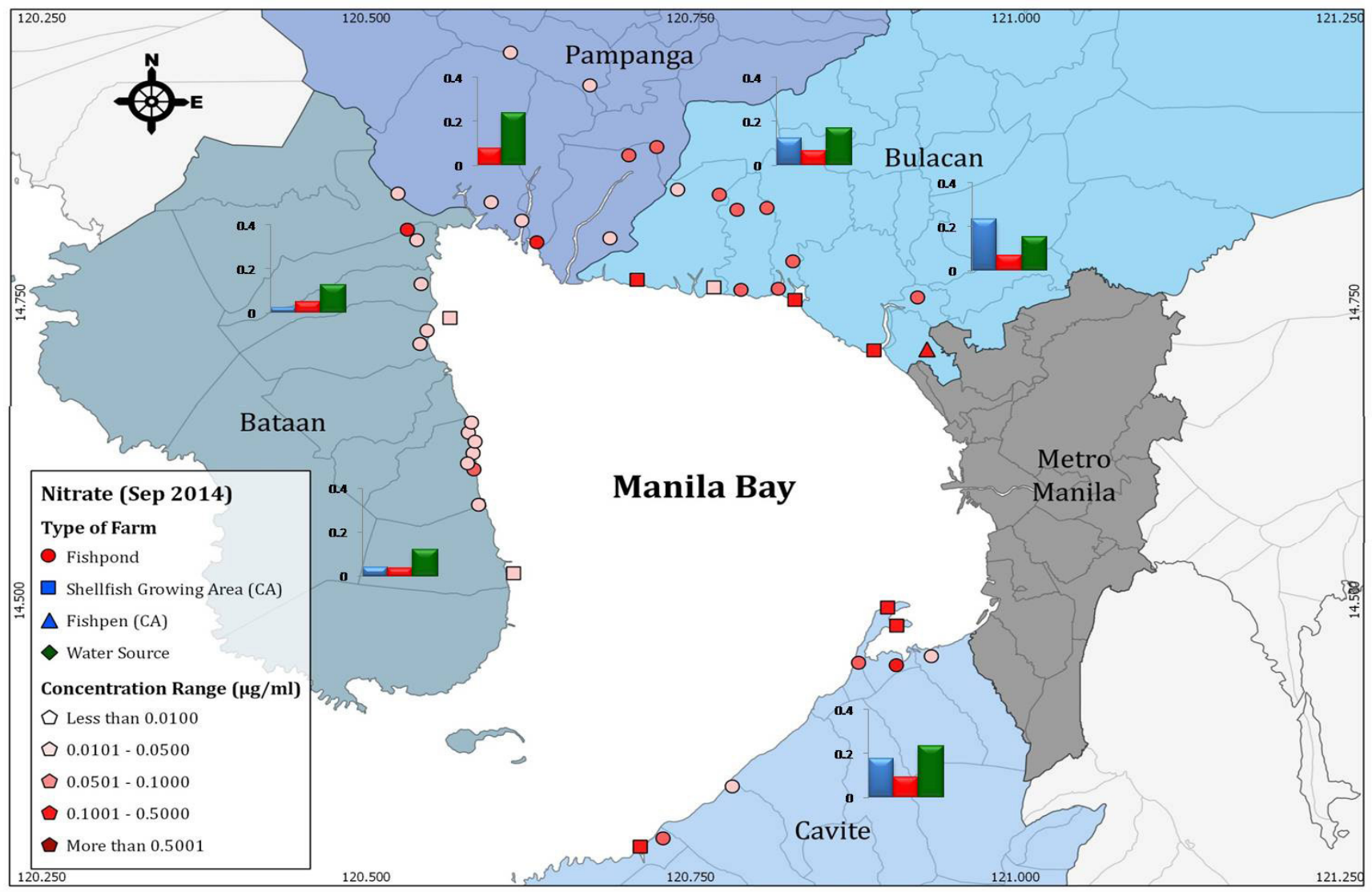

Figure 3.4b. Levels of nitrate in coastal areas/fish pens, ponds, and water sources in September 2014. 


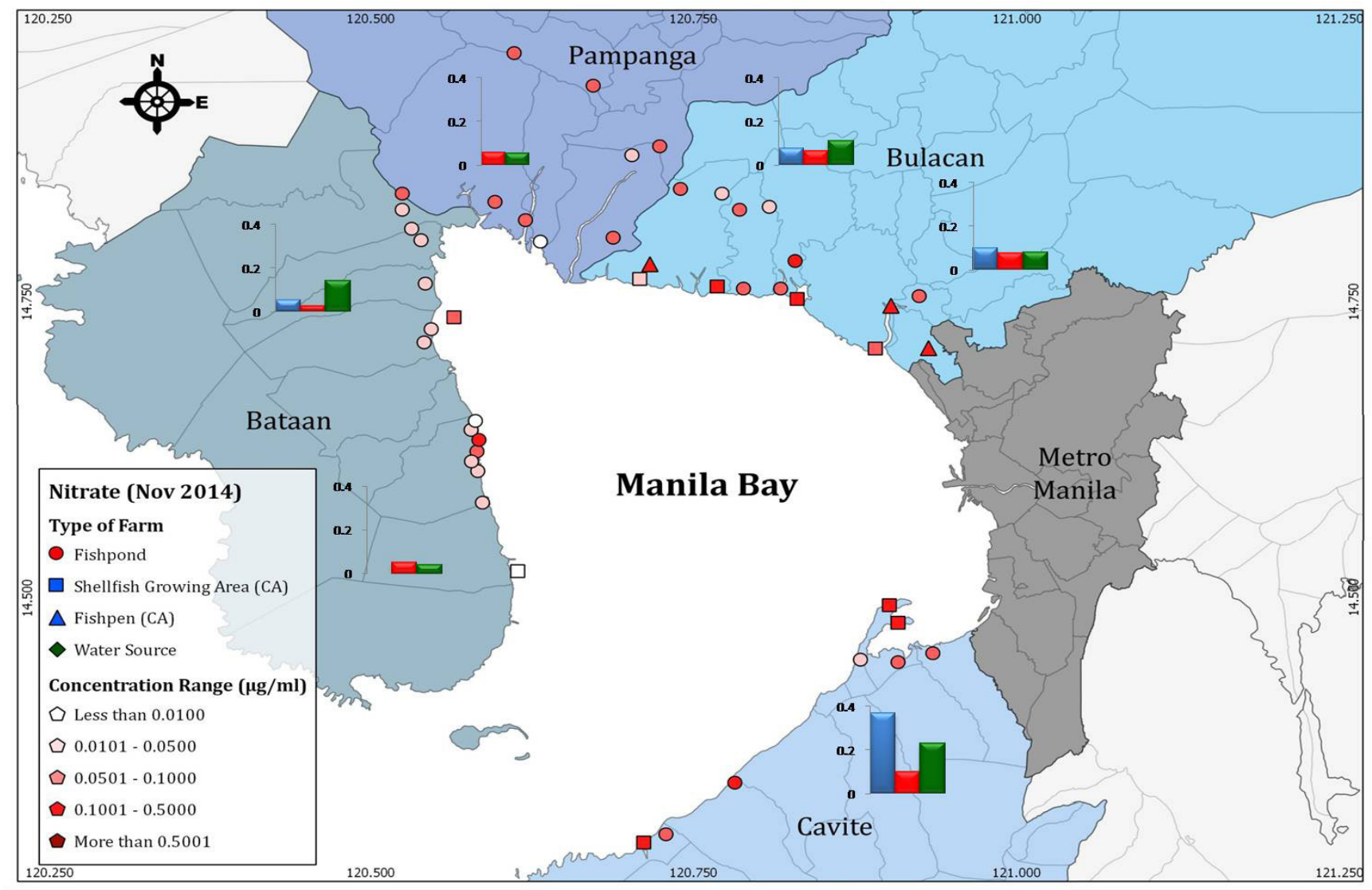

Figure 3.4c. Levels of nitrate in coastal areas/fish pens, ponds, and water sources in November 2014.

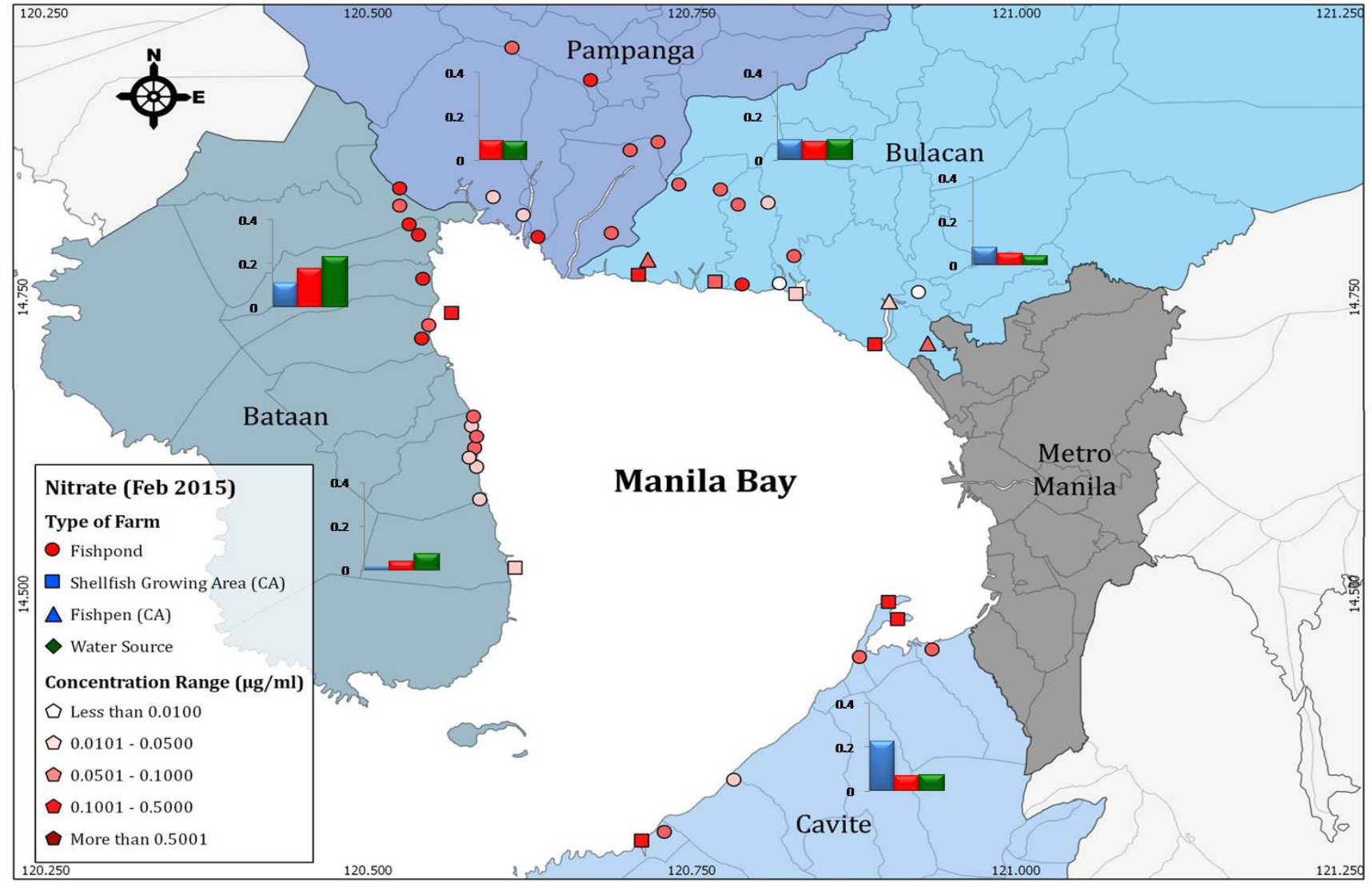

Figure 3.4d. Levels of nitrate in coastal areas/fish pens, ponds, and water sources in February 2015. 


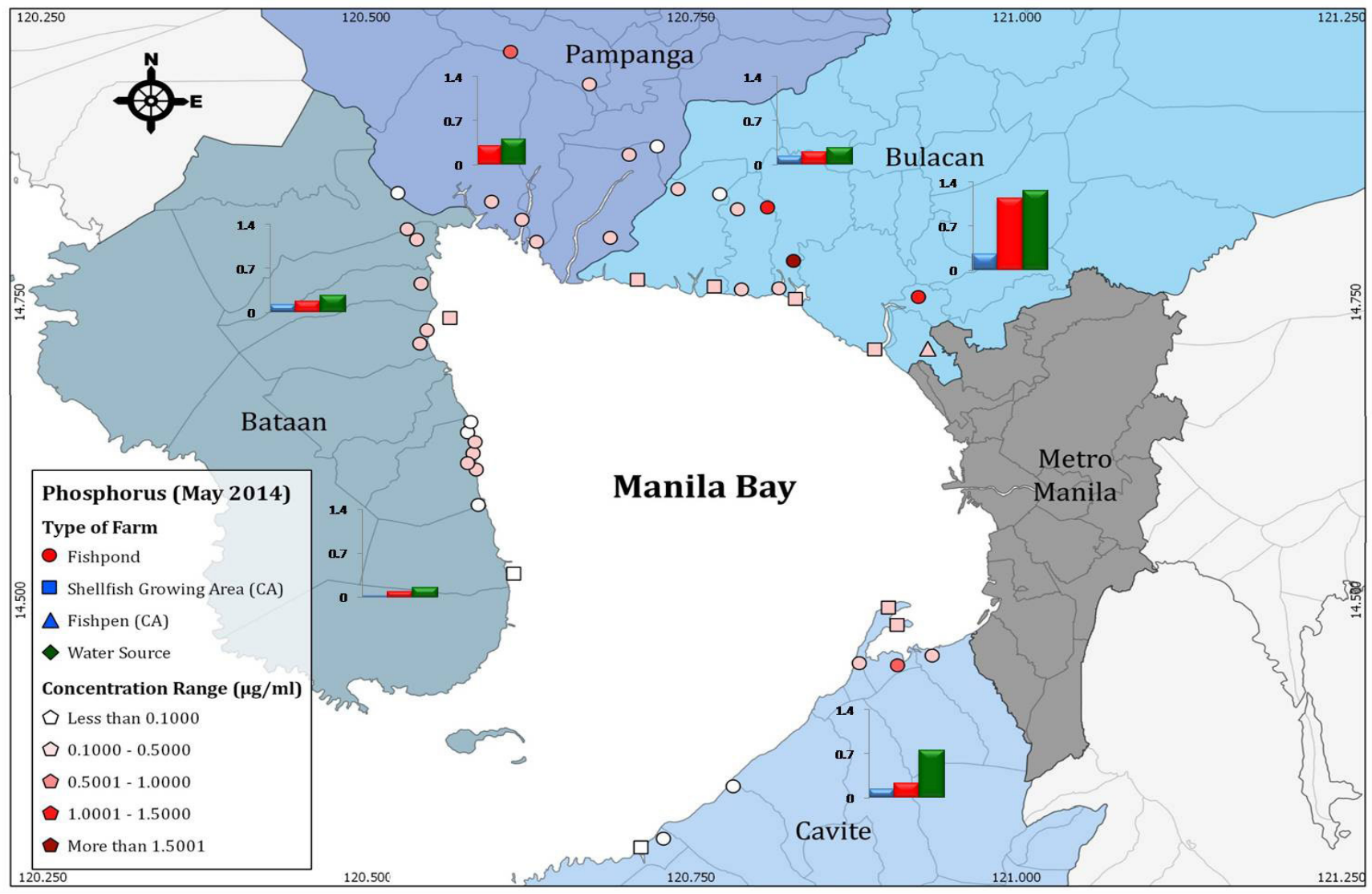

Figure 3.5a. Levels of phosphorus in coastal areas/fish pens, ponds, and water sources in May 2014.

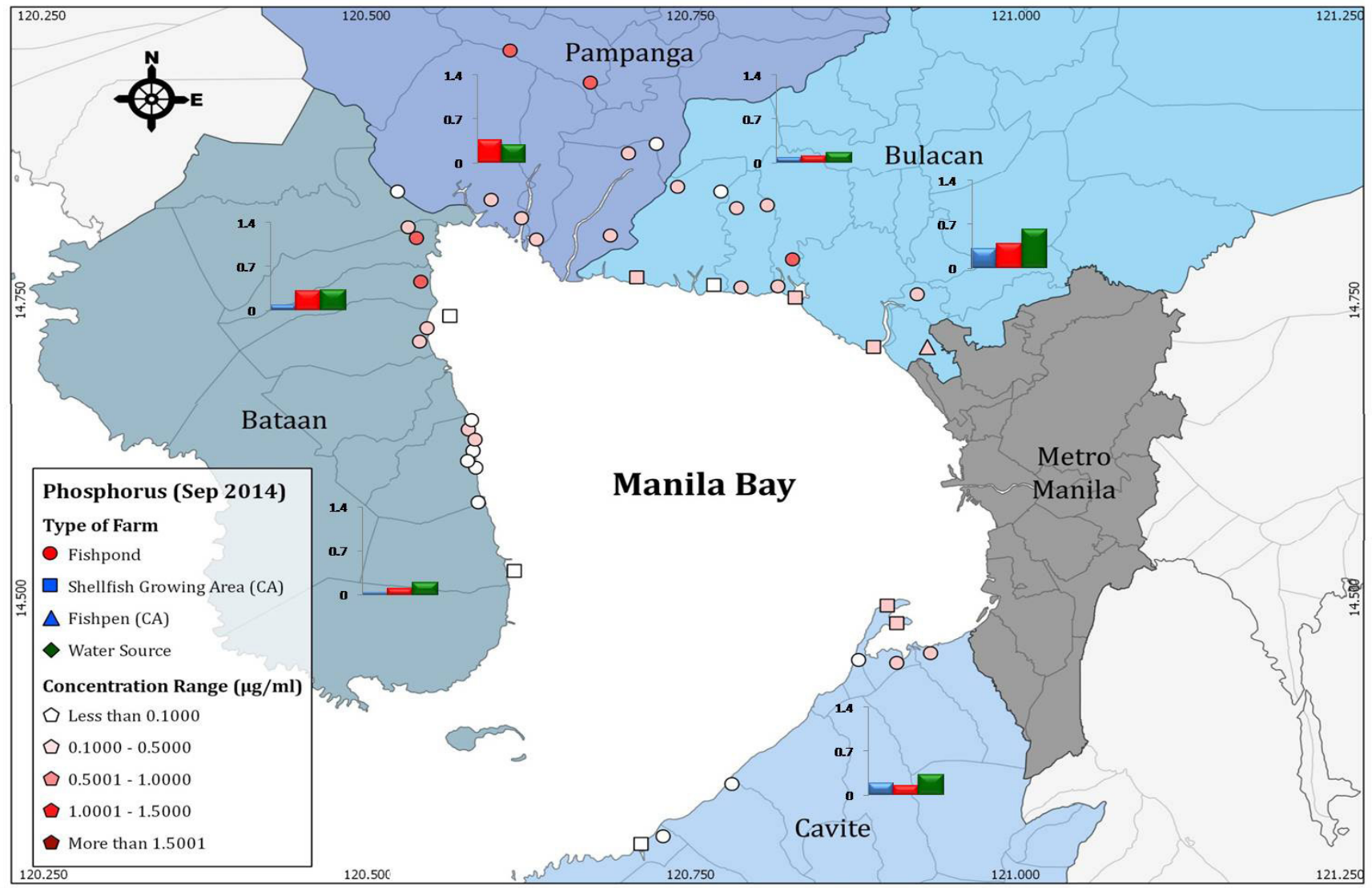

Figure 3.5b. Levels of phosphorus in coastal areas/fish pens, ponds, and water sources in September 2014. 


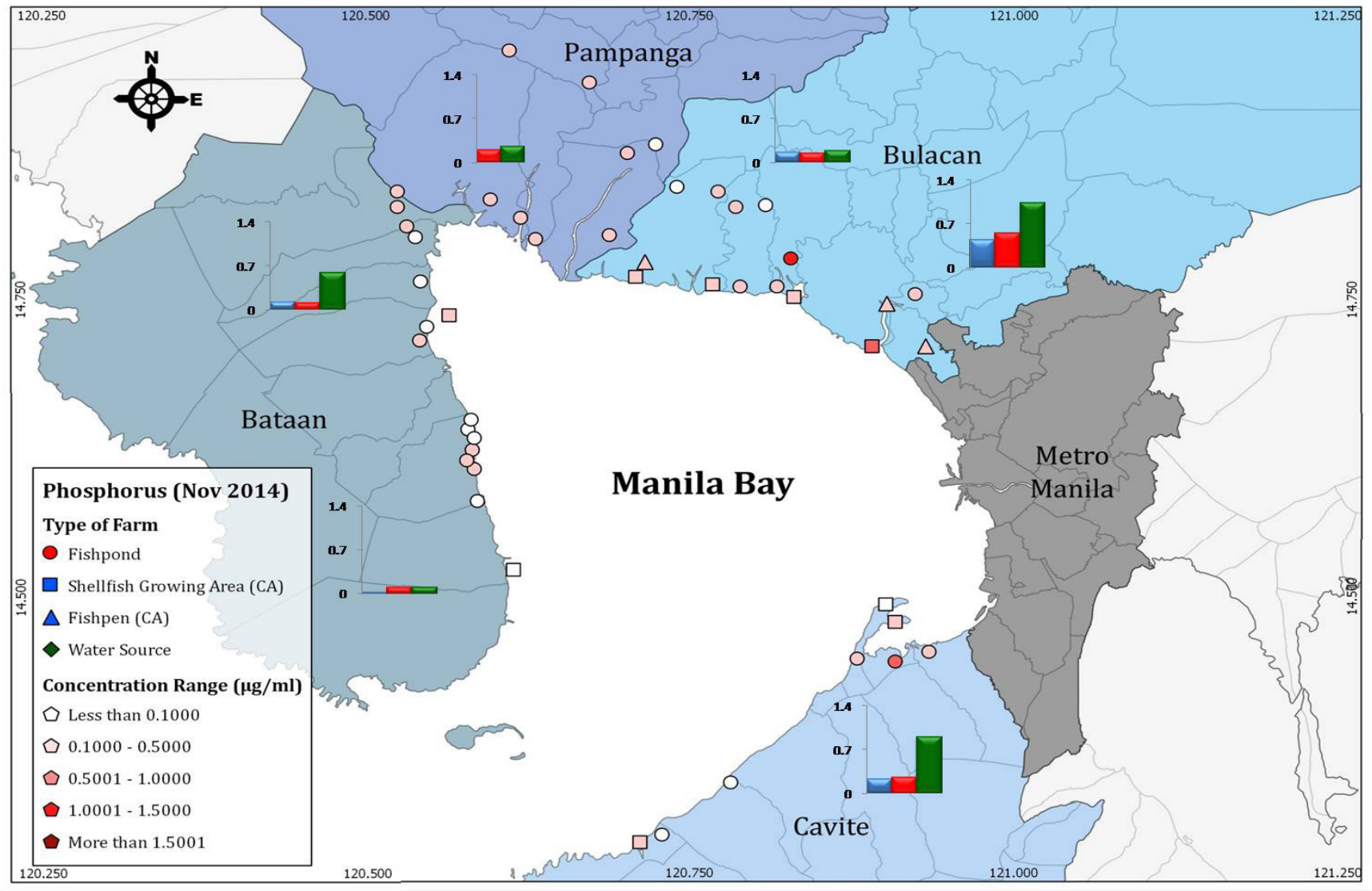

Figure 3.5c. Levels of phosphorus in coastal areas/fish pens, ponds, and water sources in November 2014.

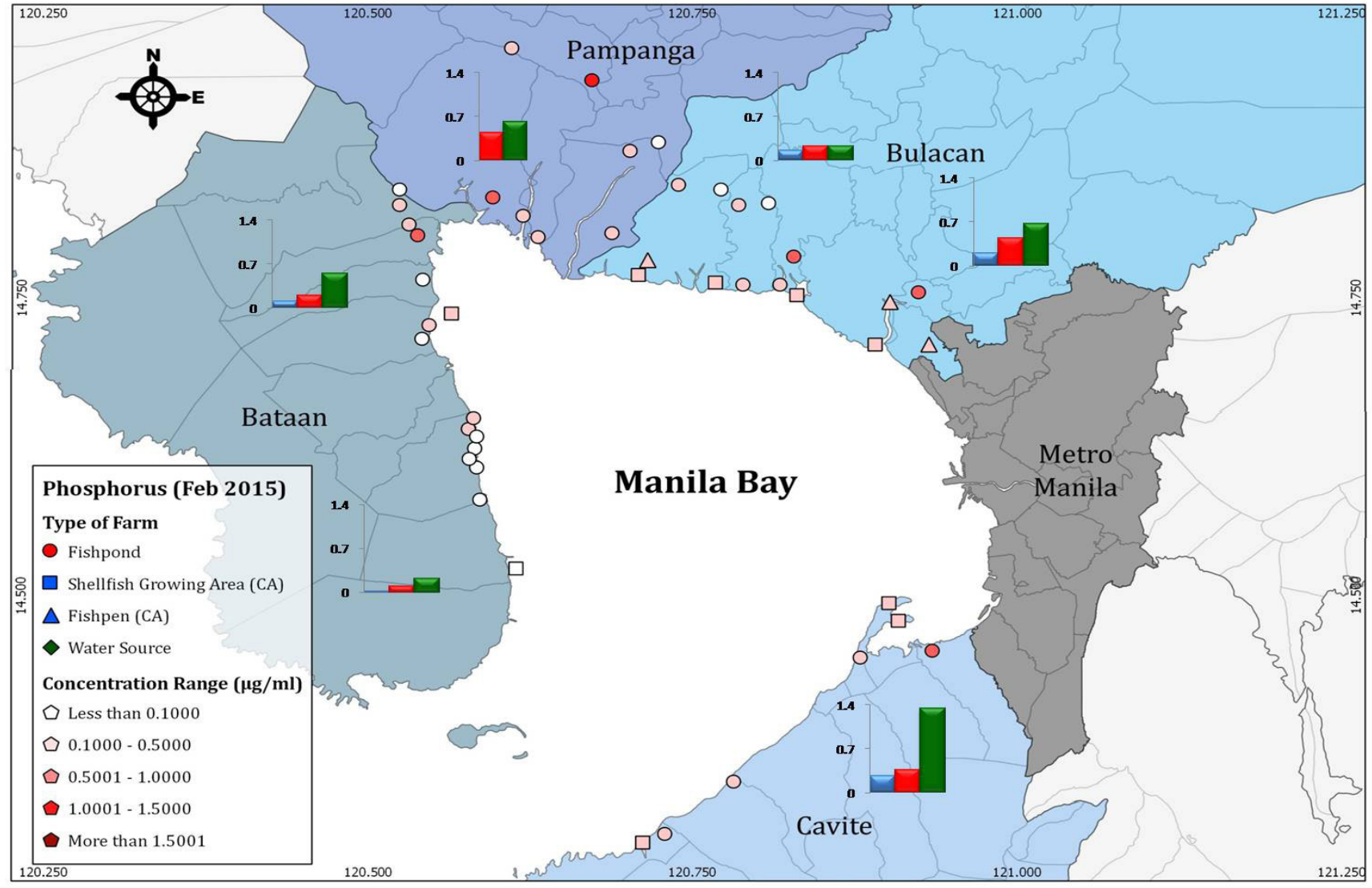

Figure 3.5d. Levels of phosphorus in coastal areas/fish pens, ponds, and water sources in February 2015. 


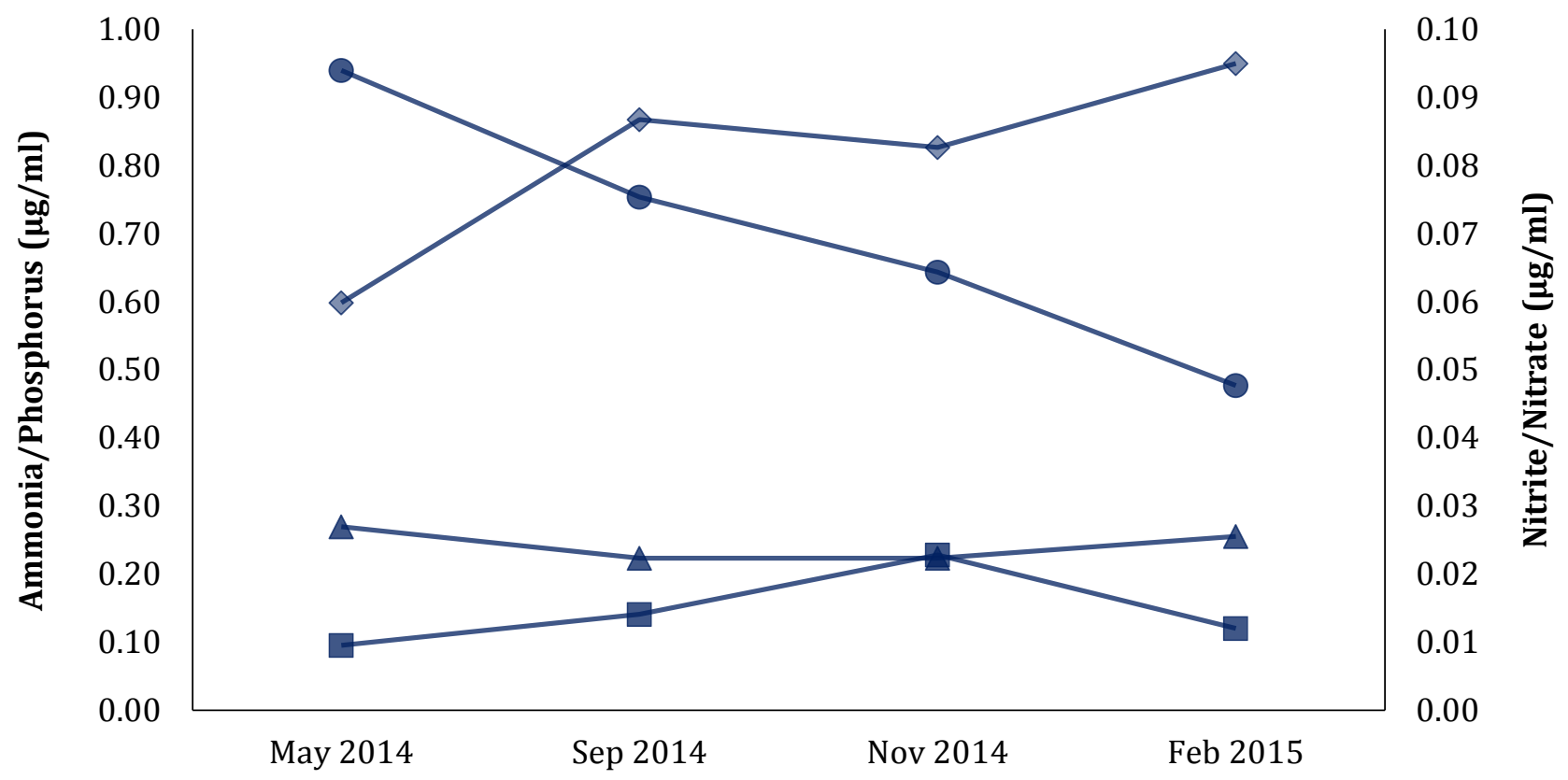

Figure 3.6. Seasonal trend of nutrient levels (mean concentrations in all blocks) in aquafarms. - Ammonia $\longrightarrow$ Phosphorus $\longrightarrow$ Nitrite $\longrightarrow$ Nitrate

and 0 to $6.19 \mu \mathrm{g} / \mathrm{g}$, respectively.

Comparing the sampling months, it can be further observed that the levels of ammonia, nitrate, and total phosphorus were high in September 2014 whereas, nitrite was high in May 2014. Moreover, the concentrations of nitrogen and phosphorus in fish ponds in most blocks were relatively higher compared to fish pen and shellfish growing areas.

\section{Linear Correlation of Nutrient in Sediment with Water}

Figures 3.11 and 3.12 show the correlation of nutrients in water and sediments during the May and September sampling. It can be observed that there is a weak correlation of ammonia in sediments and in water. Nitrates and nitrites did not correlate. But, phosphorus gave a good correlation between sediments and water in May.

\section{$\underline{\text { Pond Clusters }}$}

Results of cluster analyses are shown in Figures 3.13a to 3.13d. Each block was analyzed separately, so the characteristics of the cluster numbers of a certain block may differ from one another. For example, sites under cluster 1 of Eastern Bulacan may have different characteristics as that of the same cluster in Western Bulacan. As seen in the figure, the number of clusters for each block throughout the season varied from two to five with the most number of clusters in Southern Bataan during the November 2014 sampling. This indicates a heterogeneous nutrient profile among its sites. It was also observed that, even though the number of clusters in a certain block remained the same for consecutive sampling periods, the sites composed therein are dissimilar. Western Bulacan, for instance, has the three clusters in May 2014 and September 2014, but the sites in the clusters in May 2014 were distinct from those in September 2014. 

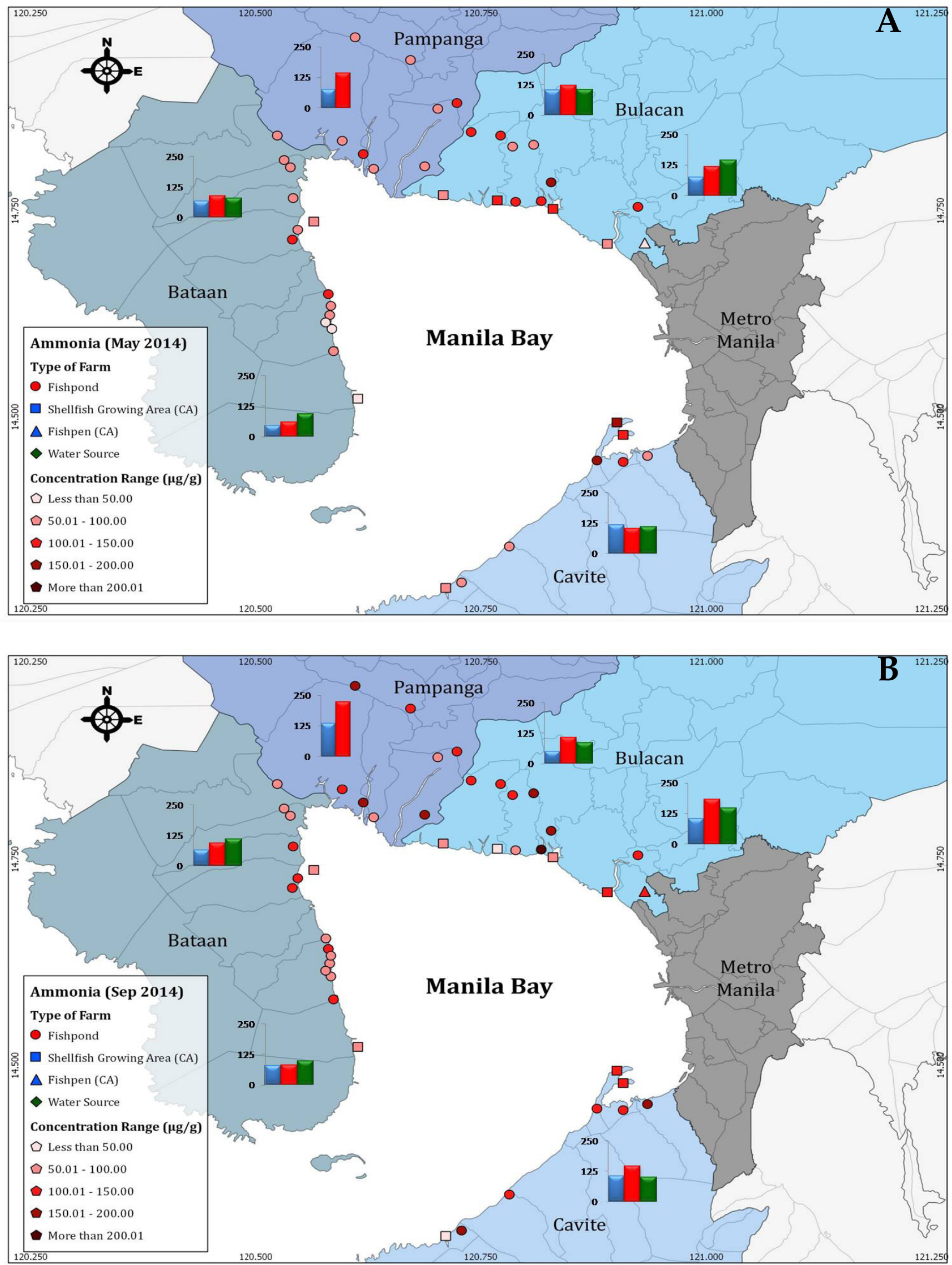

Figure 3.7. Levels of ammonia in sediments in May 2014 (A) and September 2014 (B). 

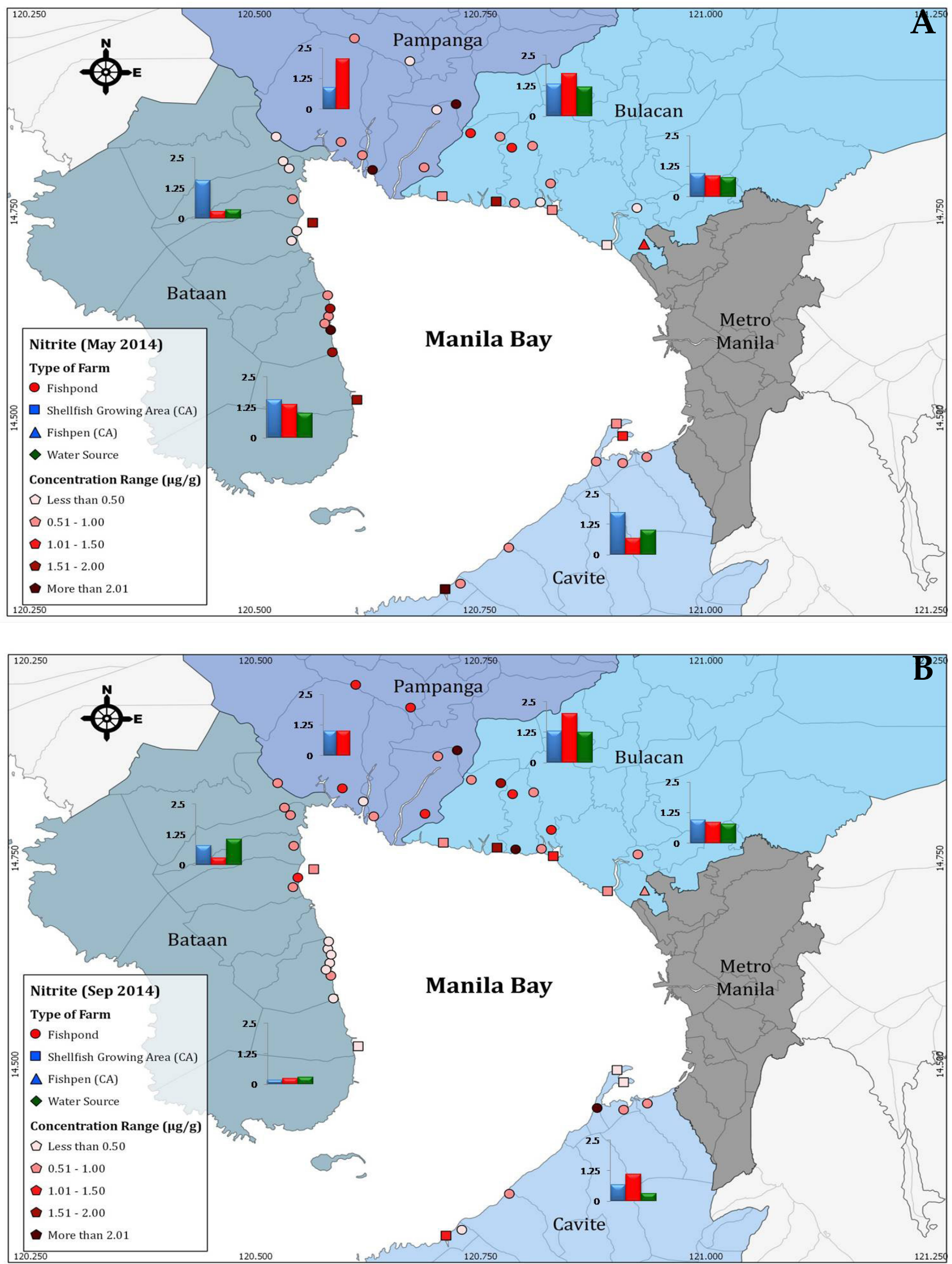

Figure 3.8. Levels of nitrite in sediments in May 2014 (A) and September 2014 (B). 

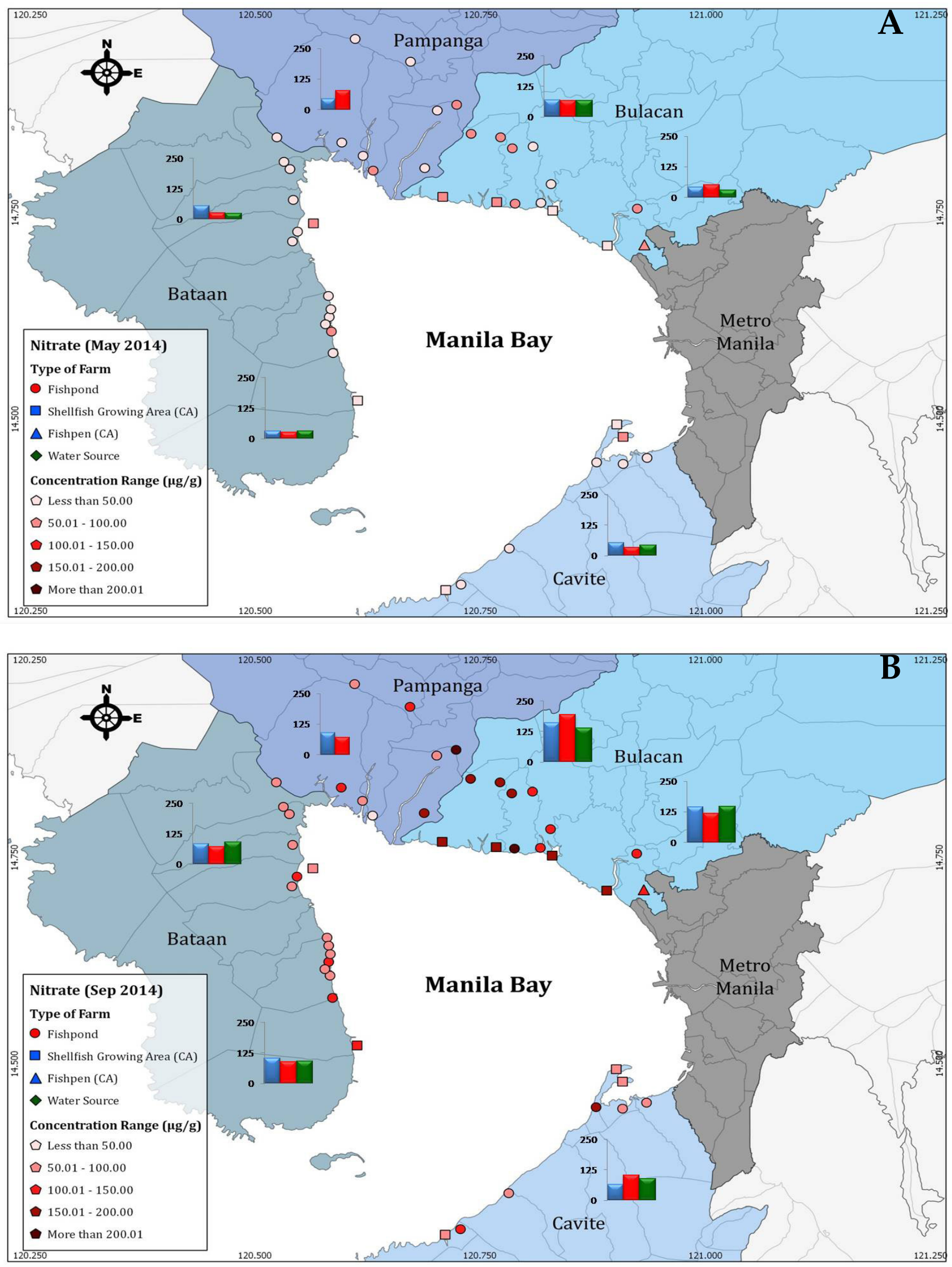

Figure 3.9. Levels of nitrate in sediments in May 2014 (A) and September 2014 (B). 

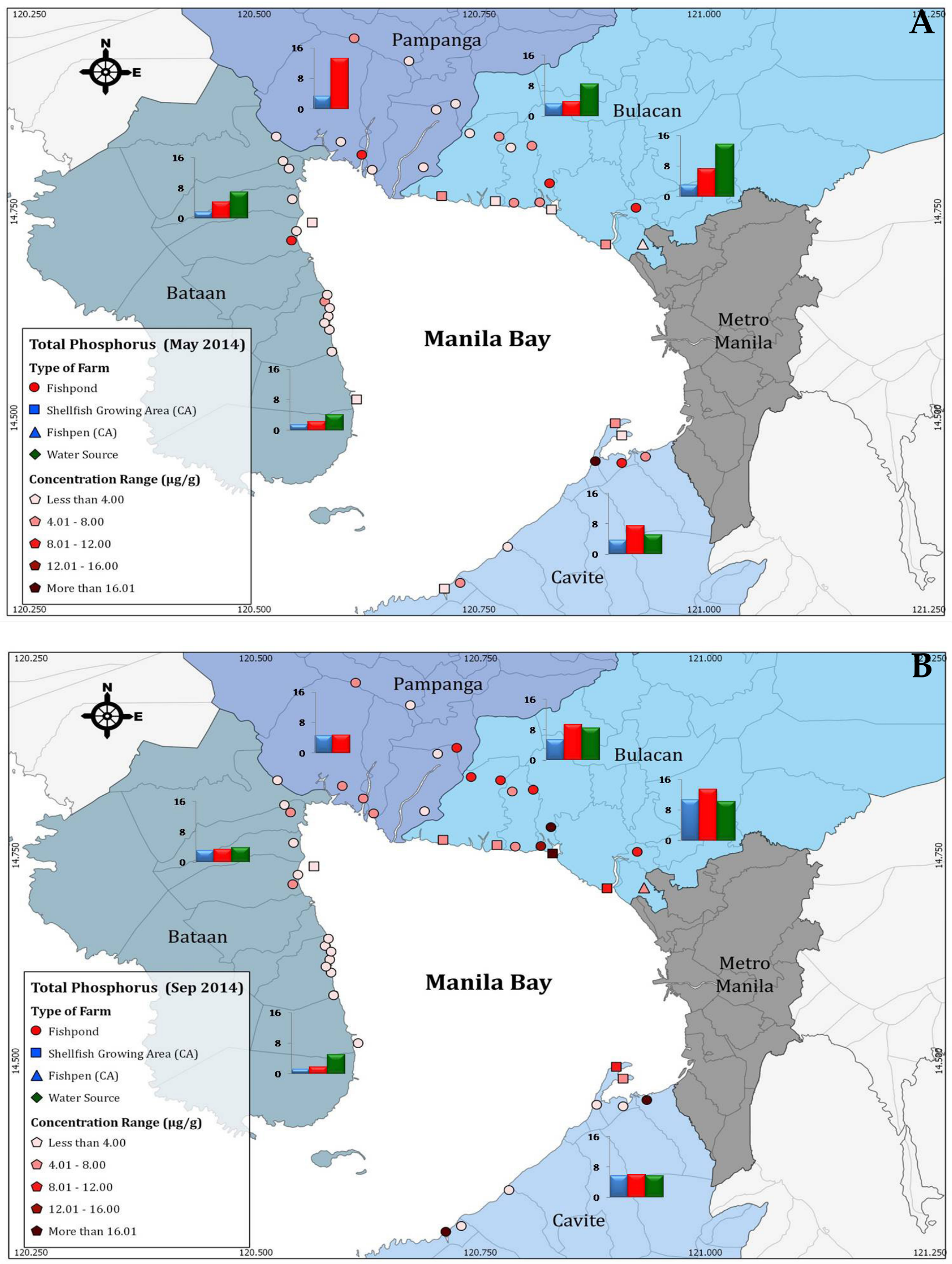

Figure 3.10. Levels of total phosphorus in sediments in May 2014 (A) and September 2014 (B). 


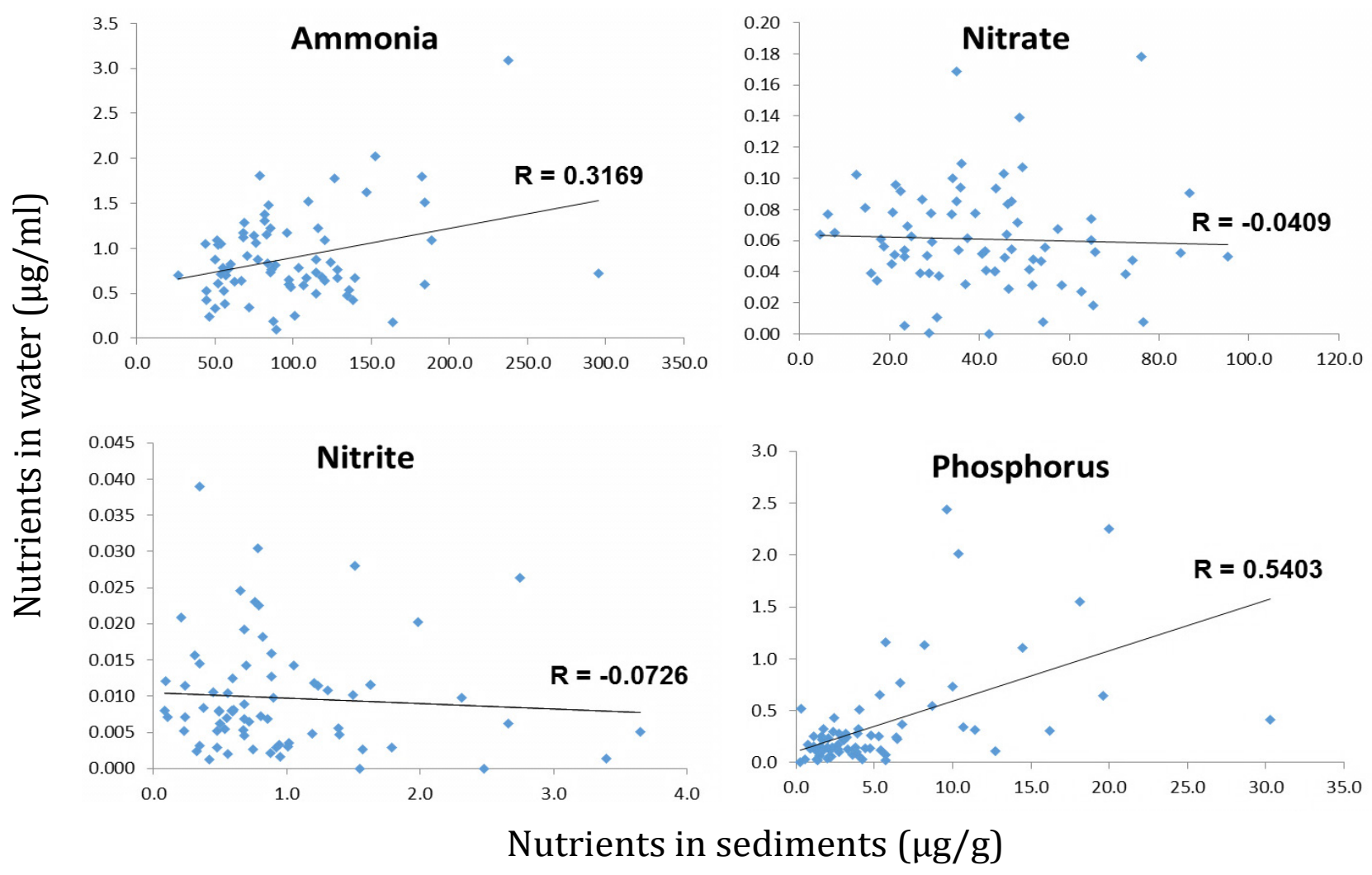

Figure 3.11. Correlation of ammonia, nitrite, nitrate, and phosphorus in sediments and water in each block (May 2014).
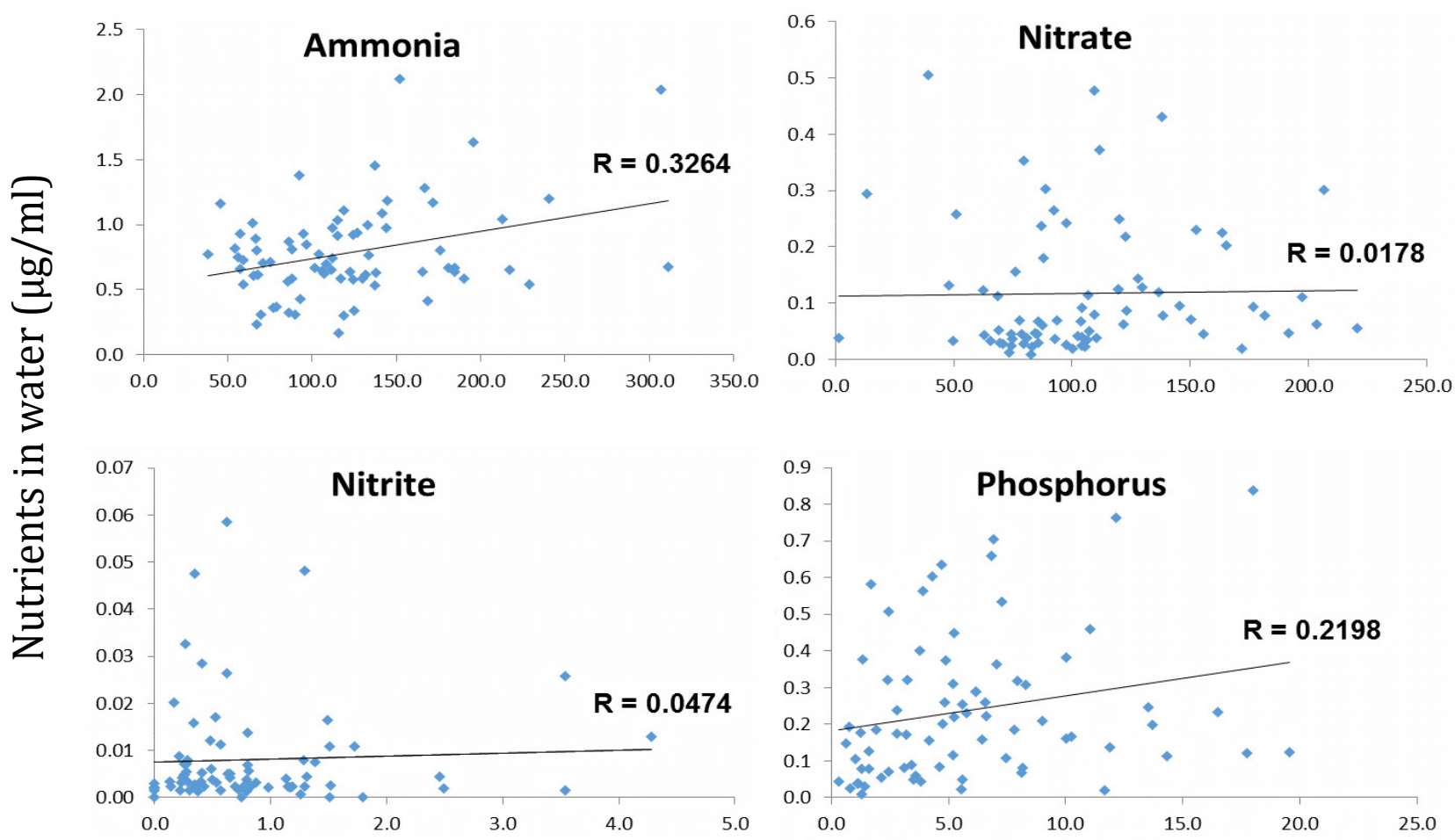

\section{Nutrients in sediments $(\mu \mathrm{g} / \mathrm{g})$}

Figure 3.12. Correlation of ammonia, nitrite, nitrate, and phosphorus in sediments and water in each block 


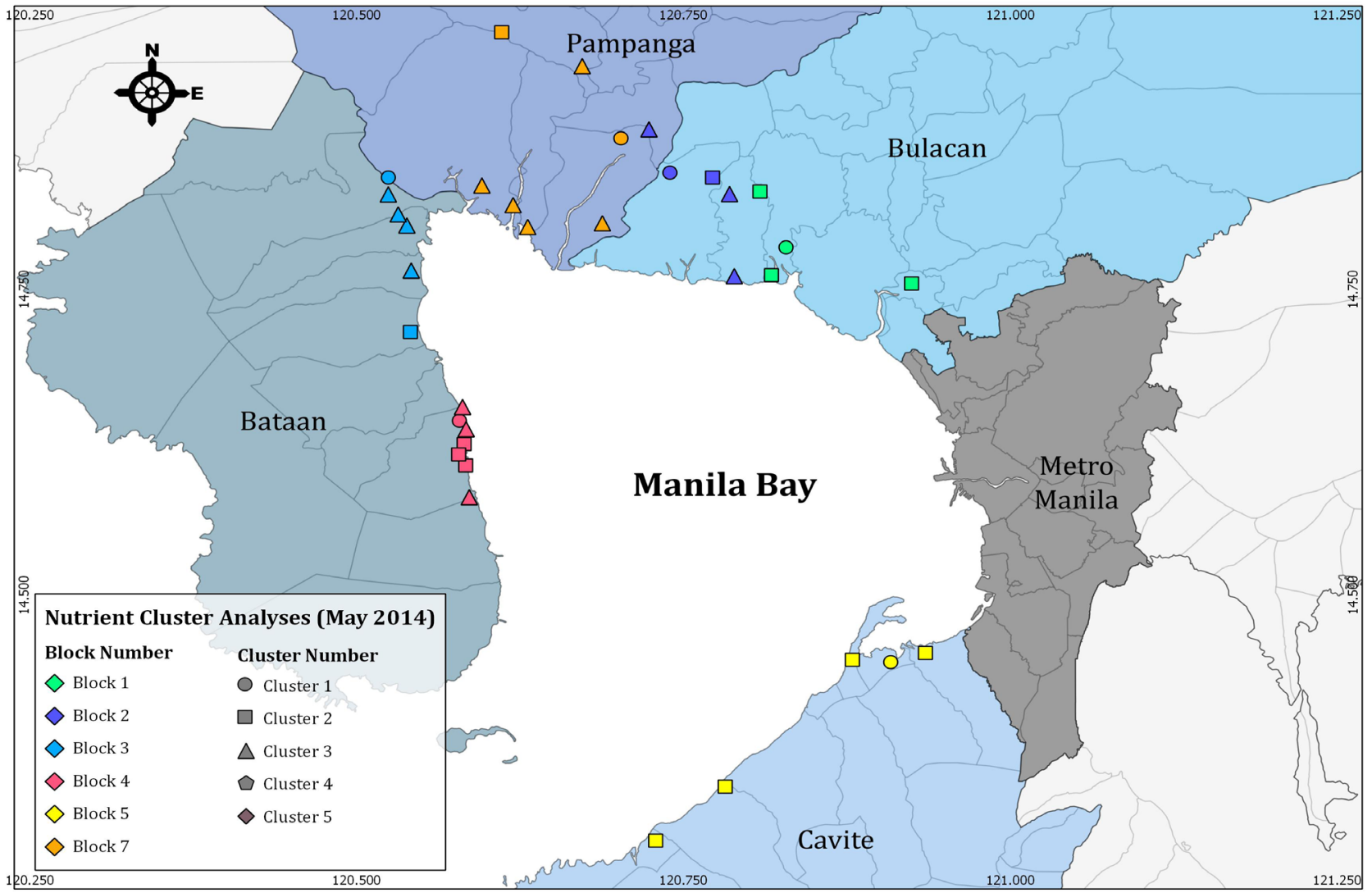

Figure 3.13a. Results of cluster analyses in the different blocks in May 2014.

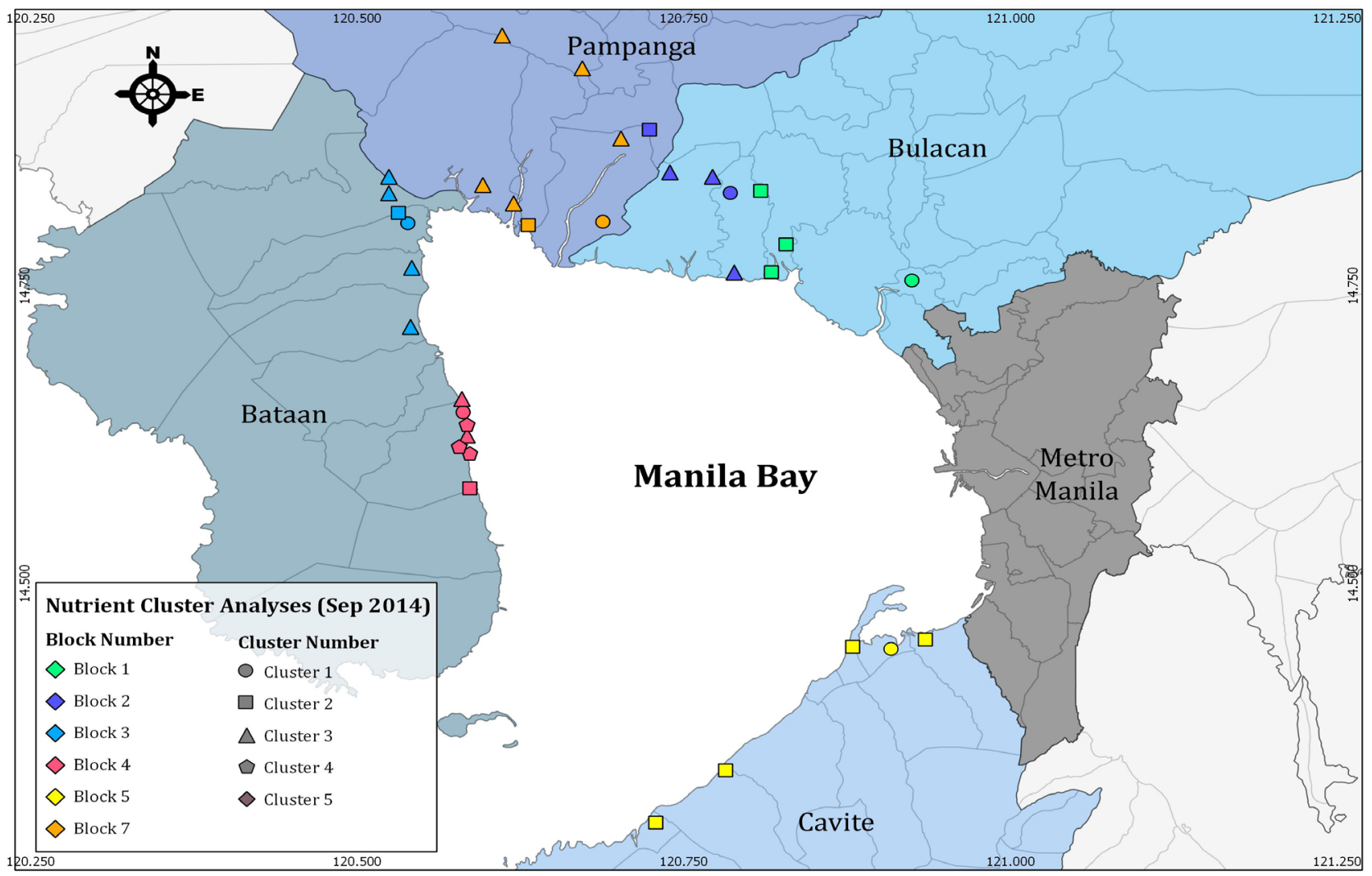

Figure 3.13b. Results of cluster analyses in the different blocks in September 2014. 


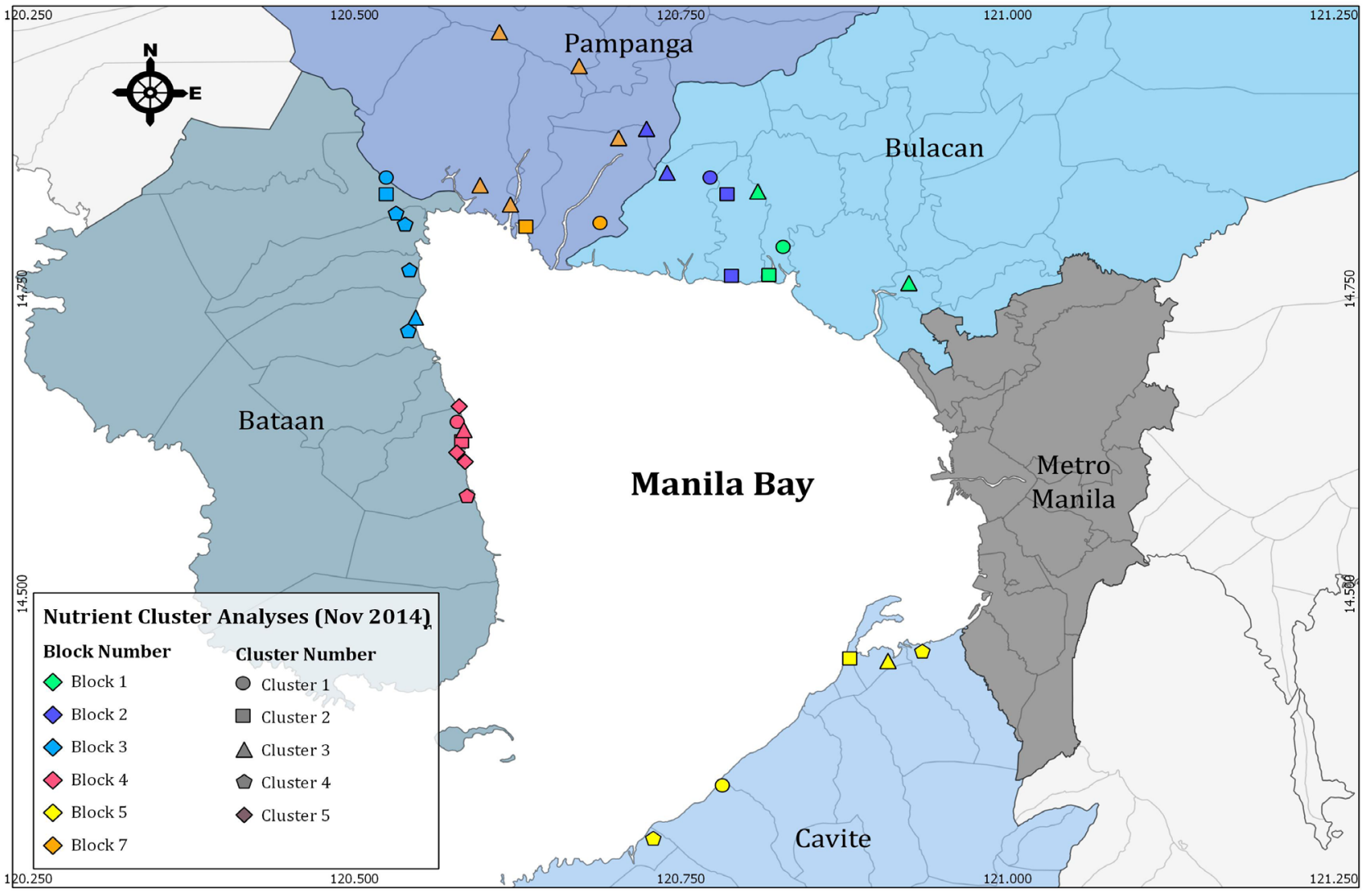

Figure 3.13c. Results of cluster analyses in the different blocks in November 2014.

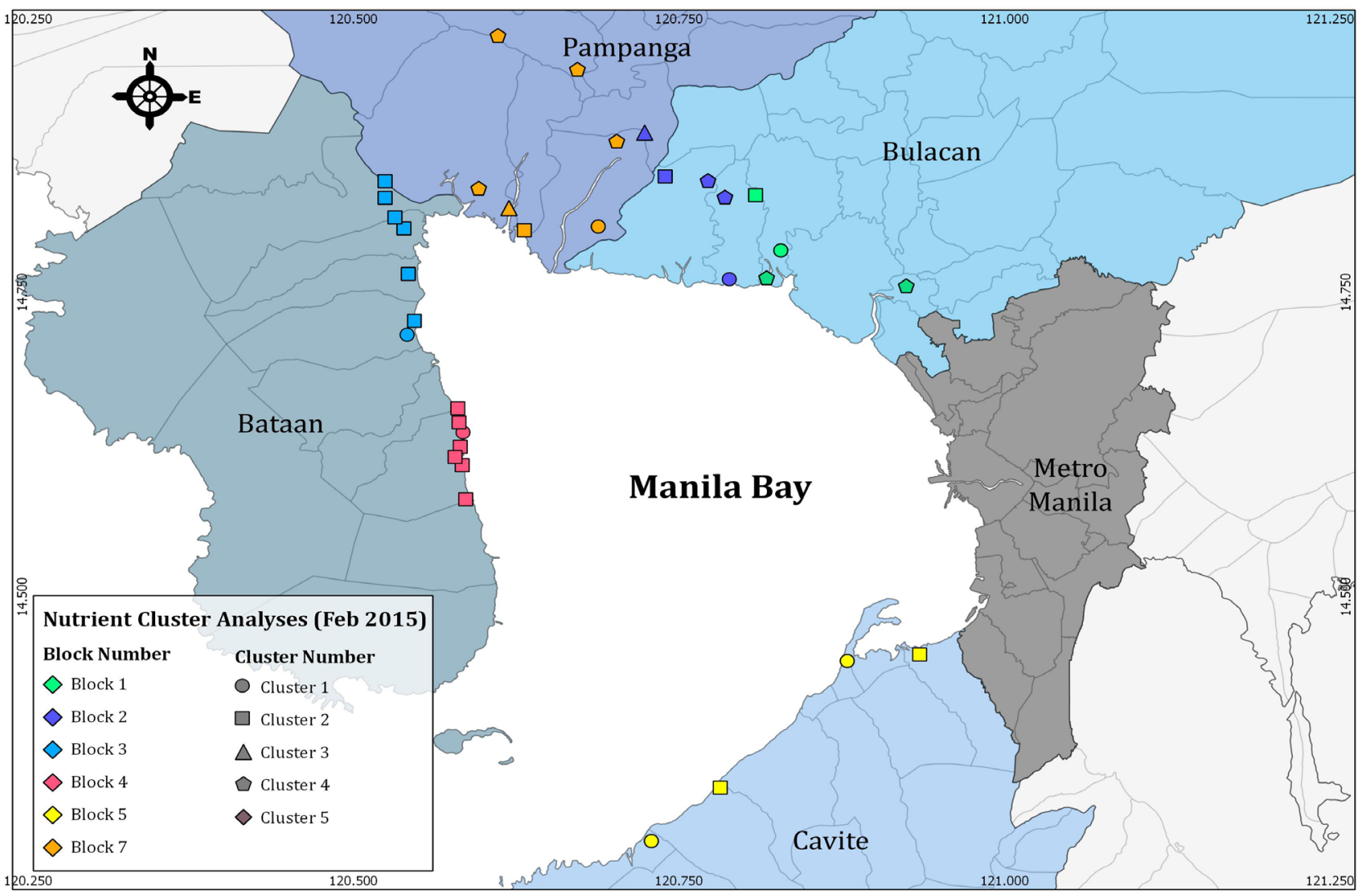

Figure 3.13d. Results of cluster analyses in the different blocks in February 2015. 


\section{Nutrient Loading}

Ammonia, nitrate, nitrite, and TKN levels in the three ponds during flooding and draining are presented in Figure 3.14. Phosphorus was not detected in any of the samples analyzed. The following are the ranges of nutrients arranged in descending order: TKN $(1.56-6.76 \mu \mathrm{g} / \mathrm{mL})$; ammonia $(0.79-4.63 \mu \mathrm{g} /$ $\mathrm{mL})$; nitrate (ND - $1.34 \mu \mathrm{g} / \mathrm{mL})$; and nitrite $(0.01-0.06 \mu \mathrm{g} / \mathrm{mL})$. Ammonia levels in both flooding and draining exceeded the regulatory limit of $0.05 \mu \mathrm{g} / \mathrm{mL}$ (DAO 2016-08) by 15.8 to 92.6 times while nitrate levels are within the regulatory limit $(10 \mu \mathrm{g} / \mathrm{mL})$.

Levels of ammonia and TKN during the flooding, which ranged from $0.81-4.63$ $\mu \mathrm{g} / \mathrm{mL}$ and $1.72-6.76 \mu \mathrm{g} / \mathrm{mL}$, respectively, were significantly higher $(\mathrm{p}<0.05)$ compared to
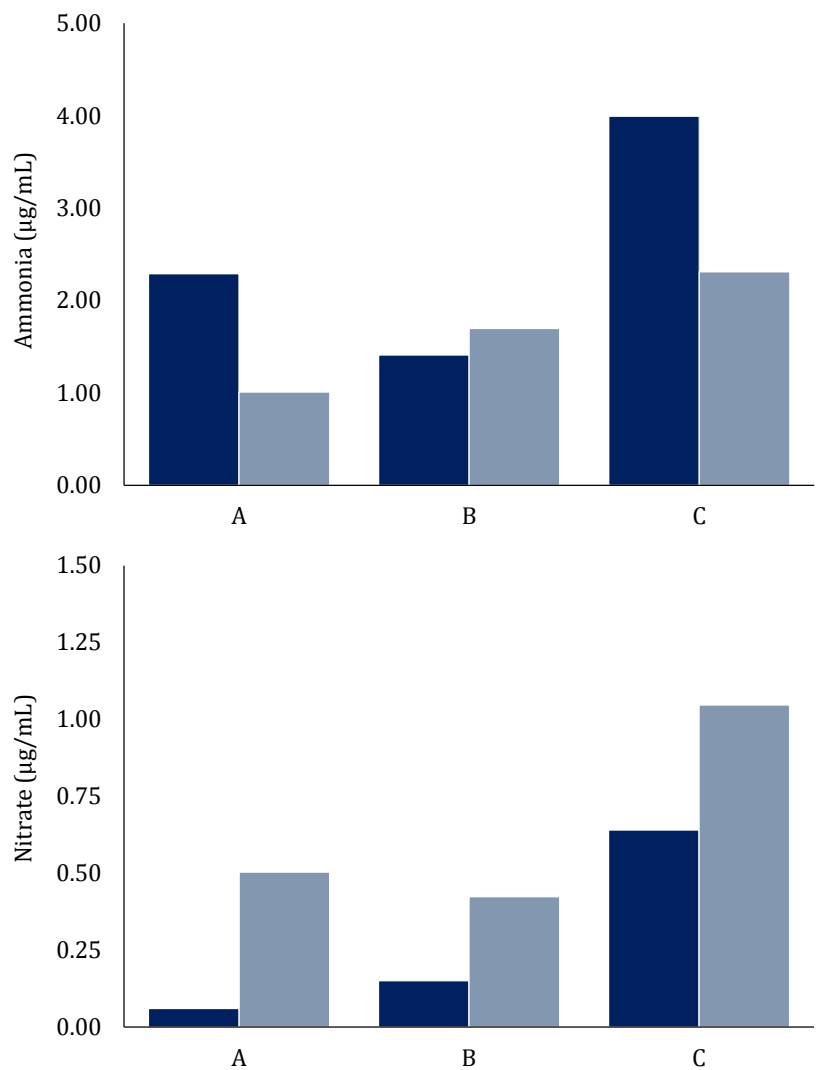

the levels during the draining, which ranged from $0.79-2.43 \mu \mathrm{g} / \mathrm{mL}$ and $1.56-2.91 \mu \mathrm{g} / \mathrm{mL}$, respectively. On the other hand, nitrate levels during the draining with levels that ranged from $0.06-1.34 \mu \mathrm{g} / \mathrm{mL}$ were significantly higher $(\mathrm{p}<0.01)$ compared to levels during the flooding that ranged from ND $-0.97 \mu \mathrm{g} /$ $\mathrm{mL}$. Nitrite levels during the draining (range of $0.03-0.06 \mu \mathrm{g} / \mathrm{mL}$ ) and flooding (range of $0.01-0.06 \mu \mathrm{g} / \mathrm{mL}$ ) are comparable with each other. Phosphorus was not detected in any of the samples collected.

As for the water quality parameters, results are reflected in Figure 3.15. Dissolved oxygen ranged from 2.38 to to $6.66 \mathrm{mg} / \mathrm{L}$, highest concentration noted in pond $\mathrm{A}$ and lowest in pond $\mathrm{C}$ during the third and first water discharge, respectively. Salinity, on the other hand, ranged from $21.10-47.40 \mathrm{ppt}$, highest in
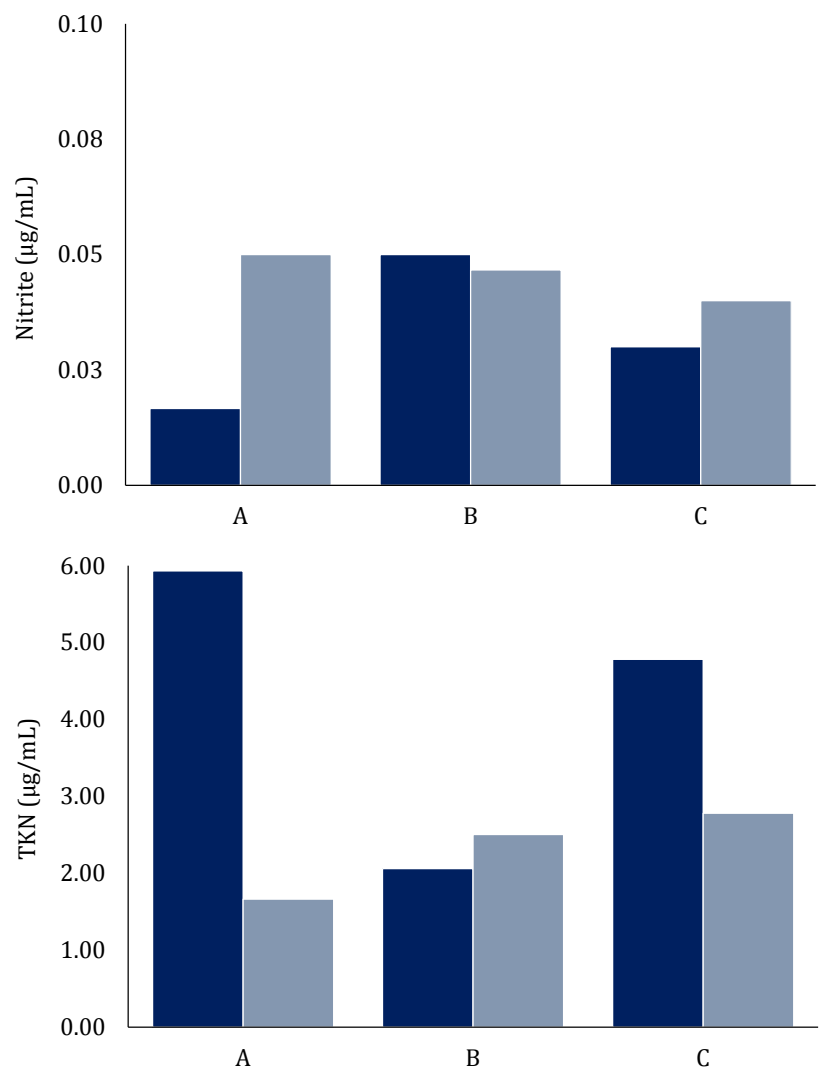

Figure 3.14. Ammonia (A), nitrite (B), nitrate (C), and TKN (D) levels during the flooding $(\square)$ and draining $(\square)$. 
pond $\mathrm{B}$ and lowest in pond $\mathrm{C}$ during the first discharge and flooding, respectively. Temperature (range of $30.90-34.68^{\circ} \mathrm{C}$ ) and $\mathrm{pH}$ (range of $7.08-8.34$ ) were both highest in pond $\mathrm{C}$ during the first and third flooding, respectively, and lowest in ponds A (third discharge) and pond $\mathrm{B}$ (third flooding), respectively.

T-test results show that dissolved oxygen $(\mathrm{p}<0.05)$ and temperature $(<0.01)$ are both significantly higher during the flooding compared to the draining. In contrast, $\mathrm{pH}$ and salinity during the flooding and draining are comparable.

The correlation between the water quality parameters and the nutrient levels in the ponds was also determined. Results are
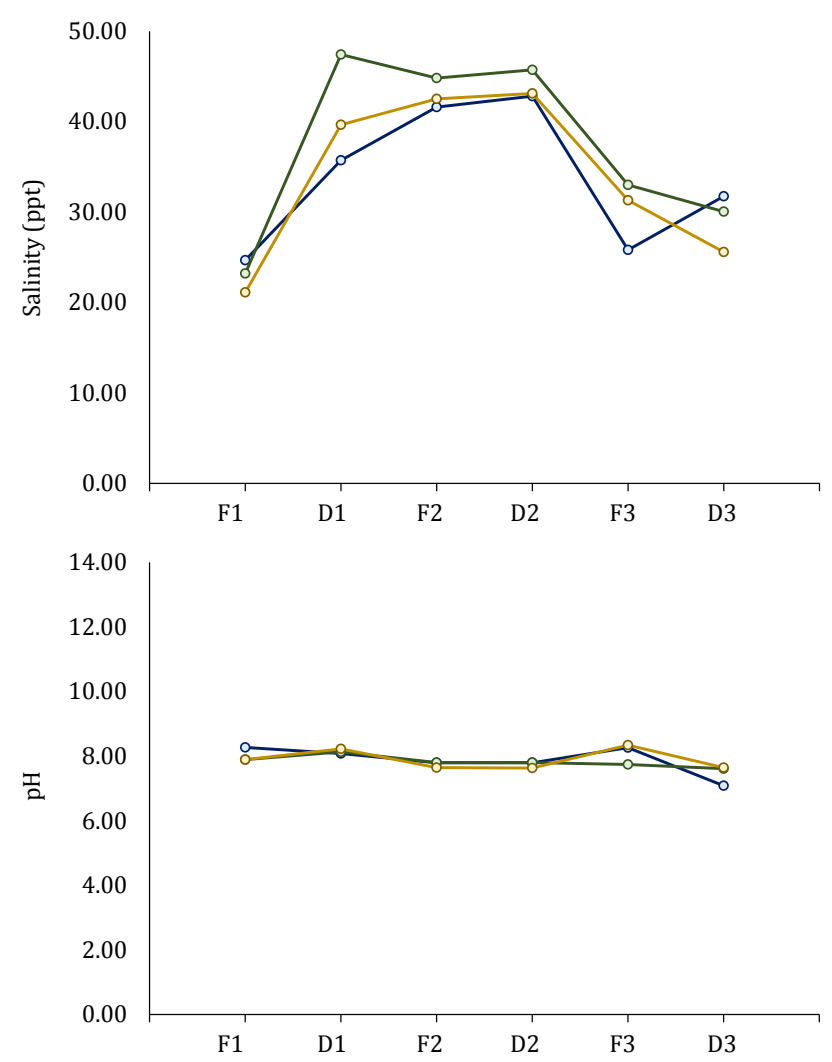

shown in Figures 3.16 to 3.19. Ammonia had a weak correlation with dissolved oxygen $\left(\mathrm{R}^{2}\right.$ $=0.3336)$ and temperature $\left(\mathrm{R}^{2}=0.2243\right)$ but had none with salinity and $\mathrm{pH}$. Nitrate had no correlation with dissolved oxygen, salinity, and $\mathrm{pH}$ but had a weak correlation with temperature $\left(R^{2}=0.2275\right)$. Nitrite and $T K N$, on the other hand, were both observed to have a good correlation with salinity $\left(\mathrm{R}^{2}\right.$ values of 0.5293 and 0.5448 , respectively) but none with the other water quality parameters.

It was also noted that other than teaseed, which was used to eradicate pests, the farmers did not apply anything else during the cropping period. Their feeding materials include low value feed, kabayo/sulib/isda, lumot, and bread, which they only feed one week before the harvest.
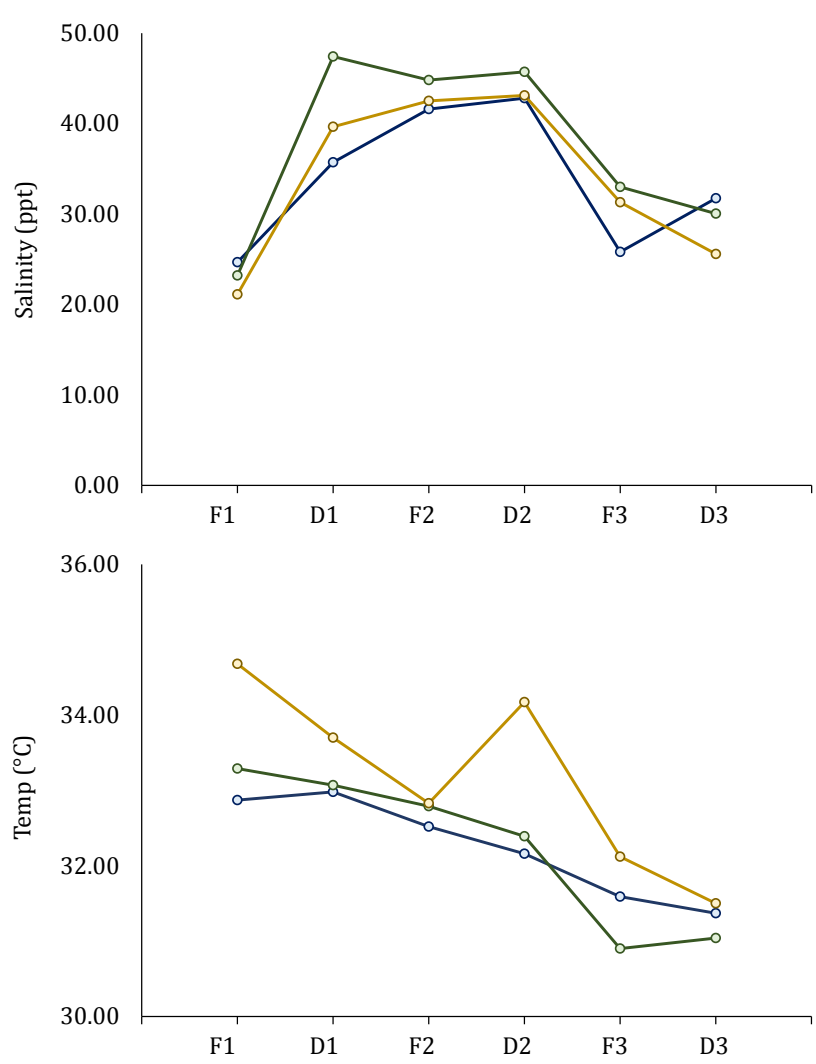

Figure 3.15. Water quality parameters of the fish ponds during the different water exchange activities. $\Longrightarrow$ NL310_A $\longrightarrow$ NL310_B $=$ NL310_C 


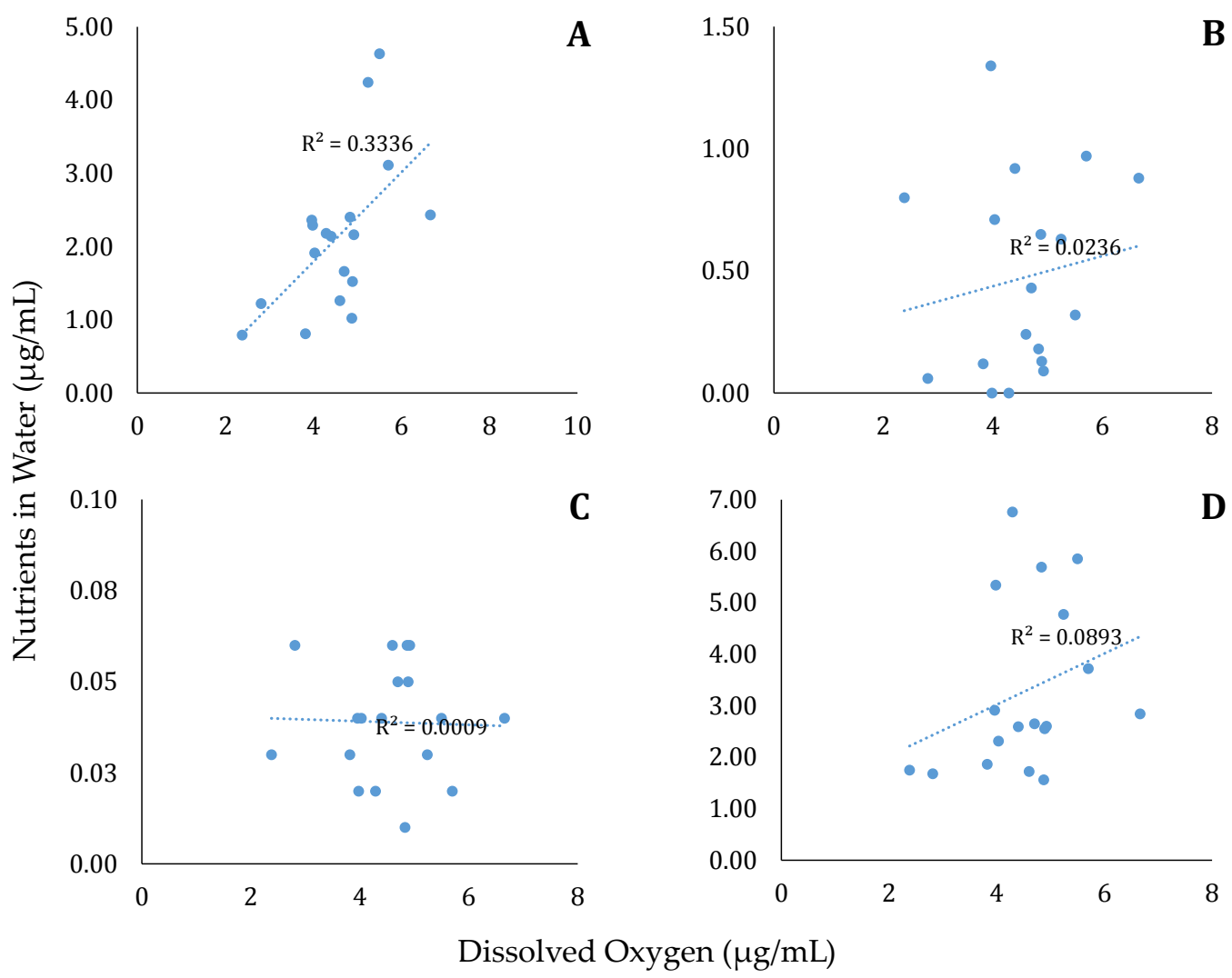

Figure 3.16. Correlation of ammonia (A), nitrate (B), nitrite (C), and TKN (D) levels in water and dissolved oxygen.

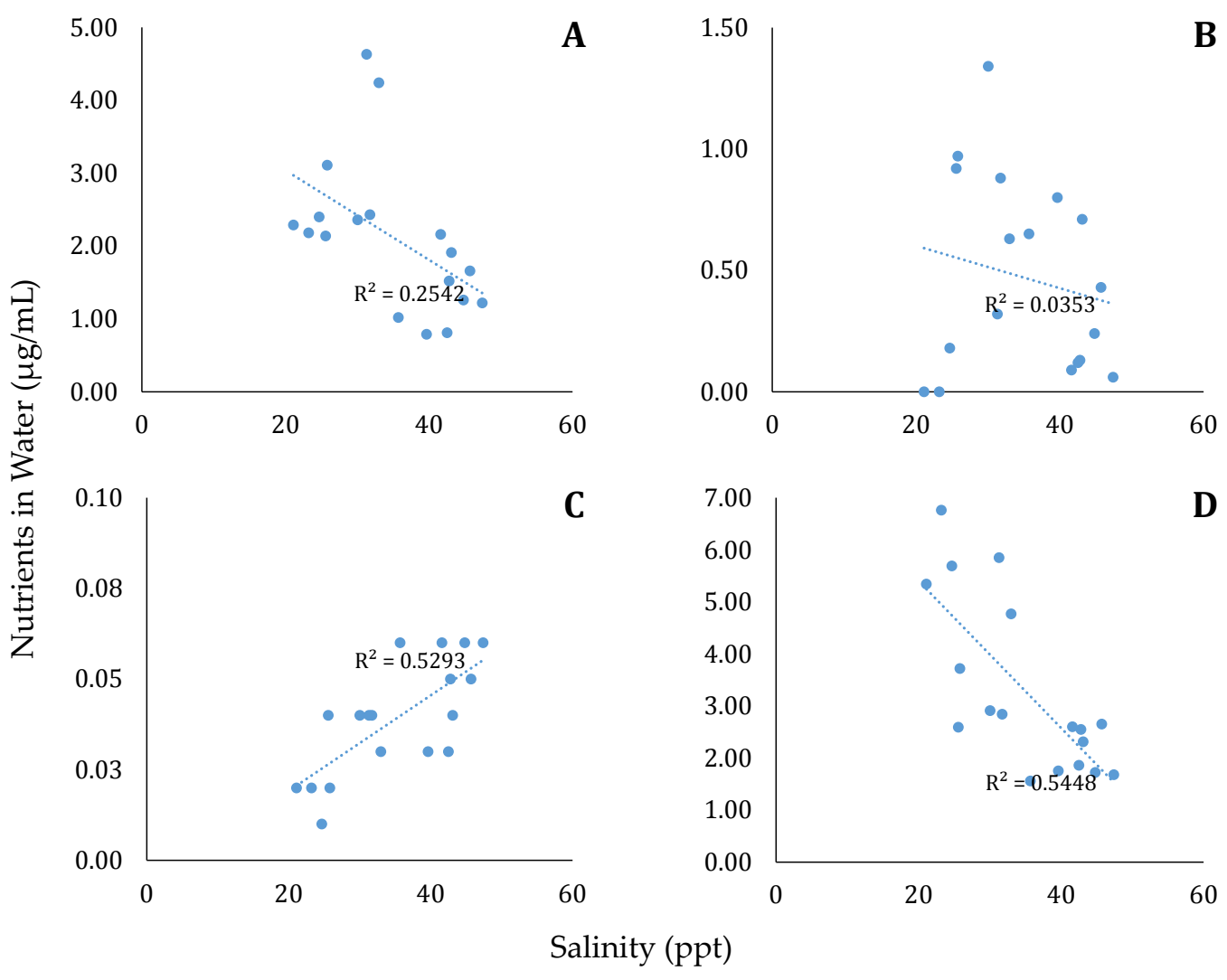

Figure 3.17. Correlation of ammonia (A), nitrate (B), nitrite (C), and TKN (D) levels in water and salinity. 


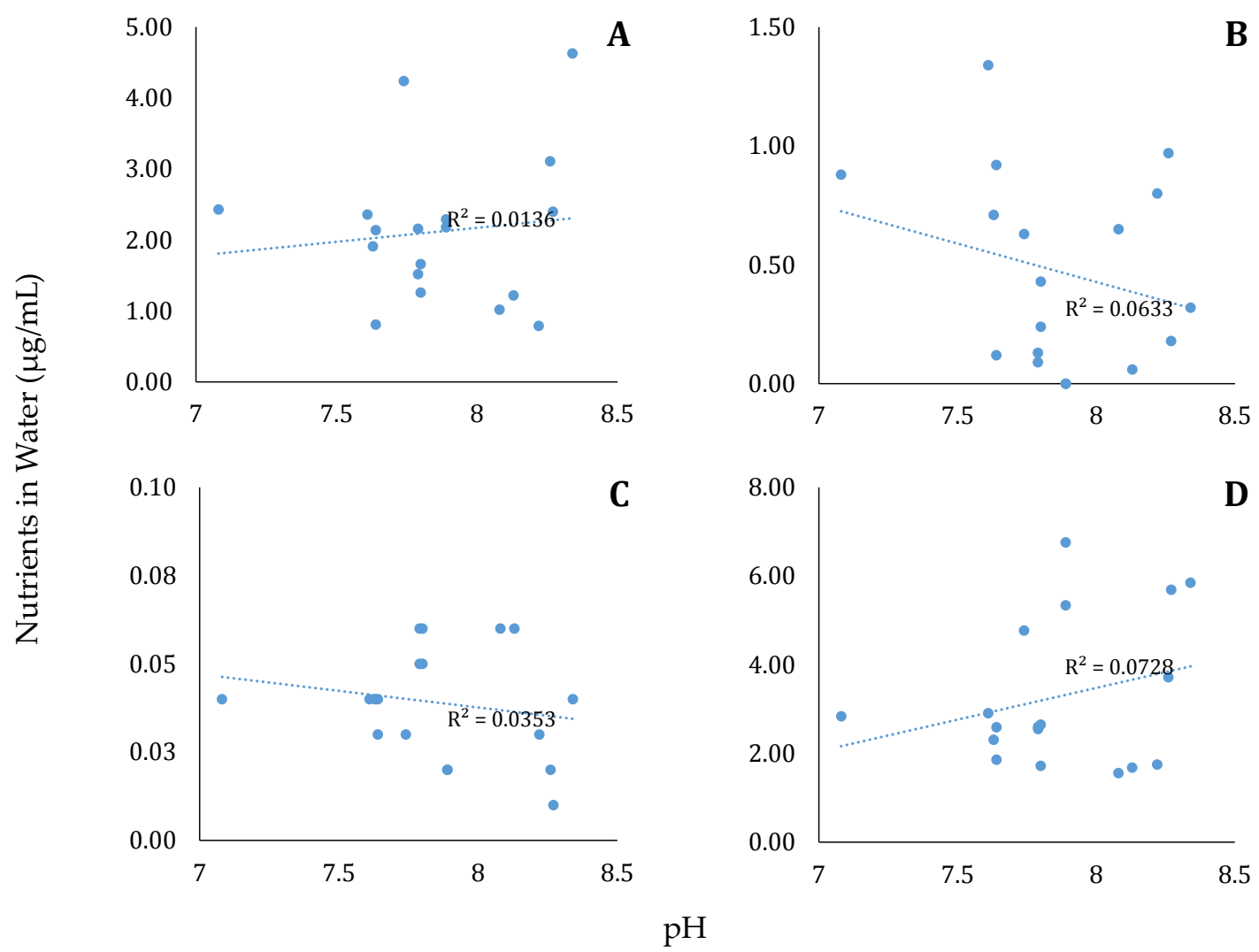

Figure 3.18. Correlation of ammonia (A), nitrate (B), nitrite (C), and TKN (D) levels in water and pH.

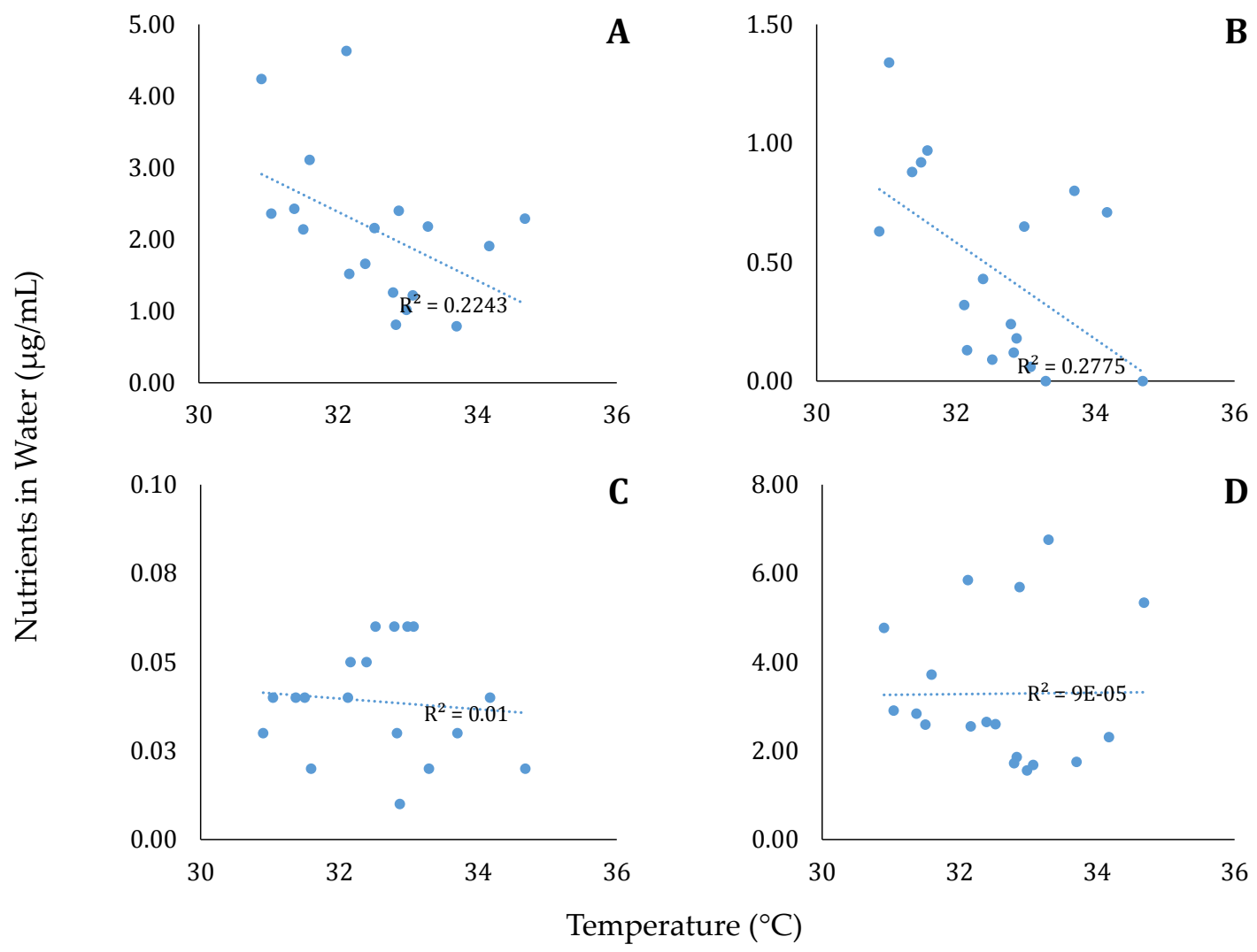

Figure 3.19. Correlation of ammonia (A), nitrate (B), nitrite (C), and TKN (D) levels in water and temperature.

\section{5}




\section{Discussion}

\section{Nutrient Levels in Water}

Results showed that ammonia levels in water samples were higher compared to other nutrient species. This is apparently because ammonia (compared to other nutrients) accumulates easily in aquatic systems due to deposition, it is the principal metabolic waste product of fish (Floyd et al, 2015; Lucas \& Southgate, 2012). Decomposition of uneaten feed or dead algae and aquatic plants, which were evident in most of the sites present in the study, further augment ammonia in the pond (Durborow et al, 1992; Floyd et al, 2015). Nitrite, on the other hand, had the least concentration since this does not accumulate in pond water because of its fast turnover rate, meaning it is easily converted to the least toxic nitrate (Gruber, 2008). Nitrate levels were found intermediate with ammonia and nitrite possibly because nitrate levels are a) dependent on the ammonia levels in the water (nitrification) and b) it has lower turnover rate than nitrite.

\section{SPATIAL NUTRIENT LEVEL}

Overall, Eastern Bulacan came out to be highly contaminated since it had the highest levels of nitrogen and phosphorus during dry and wet seasons. Relating the nutrient levels to the aquaculture practices of the farmers, it can be noted that the inputs of the farmers in Eastern Bulacan were not that intense compared to the inputs in the other blocks. Farmers in Eastern Bulacan employed the least variety of pesticides, fertilizers, and feeding materials (see Figures 2.7, 2.8, and 2.11). In fact, a high percentage of farmers did not apply any fertilizer and pesticide at all. Furthermore, the feeding materials used in Eastern Bulacan were mostly natural food, such as lablab, lumot, and surface plankton, which yield lesser nutrients. However, al- though their inputs were not intensive, the high percentage of farmers in Eastern Bulacan by-passed important pond preparation activities, such as drying of pond, soil scraping, and water flushing. Consequently, nutrients from residual wastes tended to accumulate in the pond. The location of Eastern Bulacan, being adjacent to Metro Manila, could also be a factor to the increase in nutrient levels. The same may be said of Cavite where nutrient level was second to that of Eastern Bulacan.

High nutrient-producing fertilizer and feeds, such as urea, low value feed and commercial feeds were applied in the aquafarms of Northern Bataan, Southern Bataan, and Pampanga which had lower nutrient levels because the high percentage of the respondents in the said blocks performed important pond preparation activities preventing the accumulation of nutrients.

Furthermore, the difference between the nutrient levels in the water source and fishponds was mostly insignificant. This means that the nutrients in the pond did not significantly contribute or affect the nutrient content of the water source or the river tributaries. The same is true in the case of water source contribution to fishponds.

\section{SEASONAL NUTRIENT LEVEL}

Ammonia was highest in May 2014 and lowest in February 2015. These results did not coincide with the normal seasonal variation i.e., it should be lower during summer or dry season (like that of May 2014), possibly because of the assimilation of ammonia by plankton and other aquatic plants (Suter, 2012; Durborow et al, 1992). Moreover, higher water temperature would hasten nitrification, or the conversion of ammonia to nitrate, resulting in a lesser available ammonia in the water (Hargreaves \& Tucker, 2004). However, 
these information are from researches performed in temperate countries where differences in temperature are higher than in a tropical country, like the Philippines. The metabolic rate of the culture species in relation to temperature, on the other hand, can be a factor influencing the ammonia levels in water. Increasing temperature during dry season, including the month of May, results in an increase in ammonia production due to increased metabolic rates and a switch to greater protein utilization (Chew et al, 2006).

Nitrite seasonal variation, on the other hand, was the similar to the results obtained by Manikannan et al (2011) in his study in Indian bodies of water where maximum nitrites were observed during October to December, and minimum during January to March. This can be attributed to the difference in temperature of the sampling months. Temperature range during November was found intermediate as it is a transition period from the wet and dry season of the country. This concurs with the finding of Hargreaves and Tucker (2004) that nitrite levels peak at intermediate temperature when maximum nitrification rates are favored. February, on the other hand, is considered the coldest month in the country which might cause nitrification rates to be lower resulting in lower nitrite production.

Nitrate seasonal variation is contrary to that of ammonia as discussed earlier. Technically, since the formation of nitrate involves a series of reactions, the seasonal variation should be similar to that of ammonia. However, this does not imply a non-conversion of ammonia to nitrate during that time. Possibly, ammonia production due to the increased metabolic rate (as a result of augmented temperature) exceeded the ammonia loss through nitrification and assimilation by algae in May 2014. Nitrate produced during nitrification is also taken up readily by aquatic plants (Chow, 2012) due to the increased temperature and sunlight during May, the warmest month of the year. February, on the other hand, exhibits high levels of nitrate because it is the coldest month and nitrate assimilation by plants might have been suppressed.

In the case of phosphorus, the seasonal change is relatively insignificant. This might be because phosphorus rapidly disappears from water upon assimilation by phytoplankton, macrophytes and bacteria, as well as adsorption by sediments (Boyd, 1971). Comparing the sampling months, however, phosphorus spiked in May 2014. This is probably because a process of leaching from the sediments to the water column took place (Kutty, 1987) as supported by the high correlation value obtained between sediments and water during that time.

\section{$\underline{\text { Nutrient Profile in Fishpond Sediments }}$}

Results showed that the ammonia, nitrite, nitrate, and phosphorus contents of the sediments were several folds higher than their concentration in water. This is apparently due to nitrogen and phosphorus from fertilizers (i.e., chicken manure and urea) and uneaten feeds deposited in the sediments. Moreover, it was observed that the texture of sediments is more like sludge indicating a high content of organic matter (Avnimelech and Ritvo, 2003). It should be noted that pond owners did not practice scraping of sediments during pond preparation. Apart from this, metabolic wastes from the culture species as well as wastes upstream, entering the pond through runoffs, may have been deposited into the sediments.

Between fishponds and coastal areas, the former had higher concentrations of nitrogen and phosphorus than the fish pens and shellfish growing areas. This result is expected since fishponds, unlike fish pens and shellfish growing areas, are closed or stagnant systems. As such, they tend to accumulate nutrients in 
the water and sediments. Furthermore, pollution indicators are more concentrated in fish ponds because volumes of water in these are smaller than in fish pen and shellfish growing areas.

\section{Pond Cluster}

Most sites under the same cluster were adjacent to each other. As such, they had similarities in environmental, climatic and anthropogenic conditions that could affect the nutrient levels in the ponds. Moreover, these sites also probably obtained their water from the same source or river system.

However, not all sites were clustered based on distance among them. The clustering may also be attributed to the diverse activities performed by the farmers in their respective ponds. The results of cluster analyses were correlated to the aquaculture activities of farmers. Cluster analyses results during February 2015 (Figure 3.13d) were only compared since the survey was conducted during that time. The inputs in May, September, and November 2014 were most probably different from that of February 2015.

No trend was apparent from the comparison of the cluster analyses results regarding the fertilizer and pesticide/disinfectant inputs of the farmers. This is most probably because sampling was done during the rearing period, and so the nutrients from the fertilizers and pesticides/disinfectants had already been used up or washed away. However, feeding inputs were somehow correlated with the cluster results of some sites as these were administered into the pond when the sampling was conducted. In Cavite, for example, all sites under cluster 1 used bread and lumot as feeding material, while all sites under cluster 2 uses lumot only. In Northern Bataan, on the other hand, all sites in cluster 2 used both low value feed and commercial feed combined with natural food (lumot or lablab), whereas a site in cluster 1 used commercial feed only. Four out of six sites under cluster 2 of Southern Bataan used the same feeding materials, namely lumot and low value feed. In Western Bulacan, all sites under cluster 4 used three types of feeding input which included both lablab and lumot, and differed only in the third feeding material.

The nutrient profile of other sites, where the same feeding material was used but belonged to different clusters, may have been affected by a combination of factors such as climatic, anthropogenic and other related aspect that might influence nutrient content. For instance, two sites in Pampanga used similar feeds, namely lablab, lumot, and low value feed. These sites, however, were clustered differently, most probably because the other site had a denser population than the other. Consequently, there was more waste, hence higher nutrient levels. The same could be true for sites belonging to the same cluster but given different aquaculture practice.

Clustering identifies sites that are similar in terms of nutrient levels. It is useful in reducing the number of sampling sites in each block for monitoring.

\section{Nutrient Loading}

Significantly higher levels of ammonia and TKN observed during the flooding suggest that the water entering the pond contain higher levels of both nutrients than the water initially present in the pond. Since ammonia is known to be the by-product of bacterial decomposition of organic matter such as feces and dead planktons (Auburn University, 2008), higher levels of this nutrient implies higher organic load, which in this case denotes that the water source has higher organic load. The accumulation of ammonia in the pond is toxic to fish, causing gill damage, lethargy, and eventually 
death (Hargreaves \& Tucker, 2004). Fortunately, phytoplanktons use it as a direct nutrient source and/or is broken down by nitrifying bacteria into nitrite and then into nitrate, which is less toxic. This means that the amount of ammonia in the pond positively affects the concentration of nitrite/nitrate in the medium. As can be observed from the results, nitrate and nitrite levels are significantly higher during the draining compared to the flooding. This indicates that ammonia initially present in the pond and from the water source have been transformed into nitrite/nitrate prior to draining.

Significantly higher levels of dissolved oxygen were recorded during the flooding implying that water coming in to the pond is more aerated than water going out of it. This is because water sources are continuously flowing, which means there is continuous mixing of the water column while water during draining has been stocked in the pond for a while, oxygen used up by the reared aquaculture commodity as well as by the algae, phytoplankton, and bacteria during metabolic processes.

The amount of nitrite was found positively correlated with salinity $\left(R^{2}=0.5293\right)$. This may be attributed to the inhibitory property of salt to nitrite oxidizers, blocking the conversion of nitrite species into nitrate. It is known that the oxidation of ammonia into nitrate cannot be carried out completely by a single species of bacteria, rather, it is a sequential activity accomplished by two groups of bacteria - ammonia-oxidizing bacteria and nitrite-oxidizing bacteria (Madigan et al, 2012). The population of nitrifying bacteria and the nitrification process are affected by environmental factors such as temperature, dissolved oxygen concentration, $\mathrm{pH}$, available substrate, product inhibition, and inhibitory compounds (Hellinga et al, 1998; Moussa et al, 2006). In a study by Dincer and Kargi (1999) and Vredenbregt et al (1997), it was concluded that the accumulation of nitrite at higher salt concentrations imply that nitrite oxidizers are more affected than ammonia oxidizers at increased salinity. As for the $\mathrm{pH}$, Hellinga et al (1998) reported that at a low $\mathrm{pH}$, nitrite oxidizers are predicted to grow faster and in turn increasing the amount of nitrate in the medium. However, results of the study conducted showed no correlation between $\mathrm{pH}$ and the amount of nutrients in the ponds collected. This may be attributed to the fluctuating $\mathrm{pH}$ in the pond due to the continuous water exchange activities. Temperature, on the other hand, although weak, was negatively correlated $\left(\mathrm{R}^{2}=0.2775\right)$ with nitrate. In the same study conducted by Hellinga et al (1998), it was found out that nitrite oxidizers grow faster at normal temperatures $\left(5-20^{\circ} \mathrm{C}\right)$ resulting in complete oxidation of ammonium into nitrate. However, at elevated temperatures, ammonia oxidizers grow faster than nitrite oxidizers implying that nitrite, instead of nitrate, is produced more. Lastly, dissolved oxygen increases the nitrification process, which suggests that as the concentration of dissolved oxygen increases, nitrate should also increase (Tan et al, 2013). However, results of the study show no correlation between nitrate and/or nitrite to dissolved oxygen but was positively correlated $\left(\mathrm{R}^{2}=0.3336\right)$ with the level of ammonia. This may be due to the already high amounts of ammonia present in the water entering the pond. And as was discussed earlier, water coming in to the pond has higher dissolved oxygen due to the consistent mixing of the water column.

\section{Conclusions}

Overall, the levels of nutrients varied widely among the water sources, coastal areas, and fishponds around Manila Bay. Ammonia levels were highest followed by phosphorus, nitrate, and nitrite. Comparing the different 
blocks, aquafarms in Eastern Bulacan were more contaminated evidenced by higher levels of nitrogen and phosphorus which may have resulted from farmers' bypassing important pond preparation activities. Nutrients had varying seasonal trends possibly due to the variable reactions of the nutrient species under changing climatic conditions. Furthermore, levels of ammonia, nitrite, nitrate, and phosphorus in the sediments were found several folds higher than that in the water column. Correlation analyses results of nutrients in water and sediments exhibited that only phosphorus has a good correlation. Ammonia, on the other hand, has a weak correlation, while, nitrites and nitrates have no correlation at all. These results suggest that sediments maybe a contributor of phosphorus and ammonia in water but not of nitrite and nitrate. Ammonia and TKN were significantly higher during the flooding, which suggests that water coming in to the pond already contain high levels of such nutrients. In contrast, significantly higher levels of nitrite and ntirate were observed during the draining suggesting that ammonia in the medium has been transformed into less toxic forms - nitrite and nitrate - by nitrifying bacteria.

\section{REFERENCES}

Auburn University. (2008). Uganda FISH project fisheries investment for sustainable harvest. Retrieved from http://ag.auburn.edu

Avnimelech Y. \& Ritvo G. (2003). Shrimp and fish pond soils: processes and management. Aquaculture, 220, 549-567

Boyd, C. E. (1971). Phosphorus dynamics in ponds: Proceedings of 25th Annual Conference of the Southeastern Association of Game and Fish Commissioners, pp. 418-426. Retrieved from http://
pdf.usaid.gov/pdf_docs/PNAAA417. pdf.

Carpenter, S., Caraco, N. F., Correll, D. L., Howarth, R. W., Sharpley, A. N. \& Smith, V. H. (1998). Nonpoint pollution of surface waters with phosphorus and nitrogen. Issues in Ecology, 3, $1-12$.

Chang, K.H., Amano, A., Miller, T.W., Isobe, T., Maneja, R., Fernando, S.P., Imai, H. \& Nakano, S. (2009). Pollution study in Manila Bay: Eutrophication and its impact on plankton community. Interdisciplinary Studies on Environmental Chemistry-Environmental Research in Asia, 261-267.

Chew, S. F., Wilson, J. M., Yuen, K. \& Randall, D. J. (2006). Nitrogen excretion and defense against ammonia toxicity. In Val, A. L., Almeida-Val, V. F. \& Randall, D. J. (Eds.), The Physiology of Tropical Fishes (pp. 307-379). Elsevier.

Chow, F. (2012). Nitrate assimilation: The role of in vitro nitrate reductase assay as nutritional predictor. In M. Najafpour (Ed.), Applied Biotechnology (pp. 107120). Shanghai, China: Intech.

Chow, K. W. \& Schell, W. R. (1980). The minerals. In ADCP/REP/80/11: Fish Feed Technology. Rome, Italy: FAO. Retrieved from http://www.fao.org/do crep/x5738e/x5738 e08.htm.

Conte, F. S. (2000). Pond fertilization: initiating an algal bloom. Western Regional Aquaculture Center Publication No. 104, 1-9. Retrieved from http:// aqua.ucdavis.edu/Database Root/pdf/ WRAC104.PDF.

Diaz, R., Rabalais, N. N. \& Breitburg, D. L. 
(2012). Agriculture's impact on aquaculture hypoxia and eutrophication in marine waters. Organization for Economic Cooperation and Development. Retrieved from https:// www.oecd.org/tad/sustainable-agri culture/49841630.pdf.

Dincer, A.R., Kargi, F., (1999). Salt inhibition of nitrification and denitrification in saline wastewater. Environ. Technol. 20 (11), 1147-1153.

Durborow, R. M., Crosby, D. M. \& Brunson, M. W. (1997). Nitrite in fishponds. Southern Regional Aquaculture Center Publication No. 462. Retrieved from http://www2.ca.uky.edu/wkrec/Ni tritePonds.pdf.

Durborow, R. M., Crosby, D. M. \& Brunson, M. W. (1992). Ammonia in fishponds. Southern Regional Aquaculture Center Publication No. 463. Retrieved from http://www.aces.edu/dept/fisheries/ education/ras/publications/wa ter_quality/Ammonia \% 20 in \% 20 Fish\%20Ponds\%20463fs.pdf.

Erondo E.S., \& Anyanwu P.E. (2005). Potential hazard and risks associated with aquaculture industry. African Biotechnolo$g y, 13,1622-1627$.

Floyd, R. F., Watson, C., Petty, D. \& Pouder, D. B. (2009). Ammonia in aquatic systems. Fisheries and Aquatic Sciences Department, UF/IFAS Extension, FA16. Re trieved from http://edis.ifas.ufl.edu/ fa031.

Golez, N. V. (2009). Shrimp culture. In Training handbook on rural aquaculture (pp. 97-130). Iloilo, Philippines: Southeast Asian Fisheries Development Center-Aquaculture Department.
Gruber, N. (2008). The marine nitrogen cycle: Overview and challenges. In D. G. Capone, D. A. Bronk, M. R. Muhholland, \& Carpenter, E. J. Nitrogen in the Marine Environment (pp. 1-43). Burlington, MA: Elsevier.

Hargreaves, J.A. \& Tucker, C. S. (2004). Managing ammonia in fish ponds. Southern Regional Aquaculture Center Fact Sheets. Retrieved from http:// fisheries.tamu.edu

Hardy, R.W., \& Gatlin, D. (2002). Nutritional strategies to reduce nutrient losses in intensive aquaculture. In L. E. CruzSuárez, D. Ricque-Marie, M. Tapia-Sala zar, M. G. Gaxiola-Cortés, \& N. Simoes, (Eds.), Avances en Nutrición Acuícola VI. Memorias del VI Simposium Internacional de Nutrición Acuícola (pp. 23-34). Cancún, Quintana Roo, México.

Havens, K. \& Frazer, T. (2012). Rethinking the role of nitrogen and phosphorus in the eutrophication of aquatic ecosystems: Sea Grant Department, UF/IFAS Extension, SGEF190. Retrieved from http://edis.ifas.ufl.edu/sg118.

Hellinga, C., Schellen, A.J.C., Mulder, J.W., van Loosdrecht, M.C.M., \& Heijen, J.J. (1998). The SHARON process: An innovative method for nitrogen re moval from ammonium-rich waste water. Water Science and Technology, 1998. doi: 10.1016/S0273-1223(98) 00281-9

Jacinto, G. S., Azanza, R. V., Velasquez, I. B. \& Siringan, F. B. (2006) Manila Bay: Environmental challenges and opportunities. In W. Wolanski (Ed), The Environment in Asia Pacific Harbours (pp. 309-328). Dordrecht, The Nether- 
lands: Springer.

Jacinto, G. S., Velasquez, I. B., San Diego-McGlone, M. L., Villanoy, C. L. \& Siringan, F. B. (2006) Biophysical environment of Manila Bay. In W. Wolanski (Ed), The Environment in Asia Pacific Harbours (pp. 295-308). Dordrecht, The Netherlands: Springer.

Kroupova, H., Machova, J. \& Svobodova, Z. (2005). Nitrite influence on fish: a review. Vet. Med. - Czech, 50 (11), 461 471.

Kutty, M. N. (1987). Phosphorus. In Site Selection for Aquaculture: Chemical Features of Water. Port Harcourt, Nigeria: FAO. Retrieved from http://www. fao.org/3/contents/71f37a4b-429c-5f428cad-8e05710d67e0/AC175E00.htm.

Lucas, J. S. \& Southgate, P. C. (2012). Aquaculture-farming aquatic animals and plants (2nd Ed.). Oxford: Wiley-Blackwell, pp. 1-629

Madigan, M.T., Martinko, J.M., Stahl, D.A., \& Clark, D.P. (2012). Brock Biology of Microorganisms (13th Ed.). USA: Pearson Education, Inc., pp. 1152 .

Manikannan, R., Asokan, S. \& Ali, A. (2011). Seasonal variation of physico-chemical properties of the Great Vedaranyam Swamp, Point Calimere Wildlife Sanctuary, South-east coast of India. African Journal of Environmental Science and Technology, 5 (9), 673-681.

MPCA. (2008). Nutrients: phosphorus, nitrogen sources, impact on water quality: a general overview: Minnesota Pollution Control Agency, Water Quality/ Impaired Waters \#3.22. Retrieved sites/default/files/wq-iw3-22.pdf.
Moussa, M.S., Sumanasekera, D.U., Ibrahim, S.H., Lubberding, H.J., Hooijmans, C.M., Gijzen, H.J., \& van Lossdrecht, M.C.M. (2006). Long term effects of salt on activity, population structure and floc characteristics in enriched bacterial cultures on nitrifiers. Water Research, 40 (2006), 1377-1388. doi: 10.1016/j.watres.2006.01.029

Olsen, L. M., Holmer, M., \& Olsen, Y. (2008). Perspective of nutrient emission from fish aquaculture in coastal waters: literature review with evaluated state of knowledge. $\quad$ Norge: Fiskeri-og havbruksnæringens forskningsfond, pp. 3-50. Retrieved from http://www. aquacircle.org/images/pdfdokument er/udvikling/andre/norden/fhf-nutri ents_and_aquaculture.pdf.

Ongley, E. D. (1996). Fertilizer as water pollutant. In Control of water pollution from agriculture- FAO irrigation and drainage paper 55. Rome, Italy: FAO. Retrieved from http://www.fao.org/ docrep/W2598E/w2598e00.htm.

PEMSEA. (2006). Initial valuation of selected uses and habitats and damage assessment of Manila Bay: PEMSEA Technical Information Report No. 2006/01. Quezon City, Philippines: Global Environment Facility/United Nations Development Programme/International Maritime Organization Regional Programme on Building Partnerships in Environmental Management for the Seas of East Asia (GEF/UNDP/PEMSEA), $165 \mathrm{p}$.

Perez, R. T., Amadore, L. A., \&Feir, R. B. (1999). Climate change impacts and responses in the Philippines coastal sector. Climate Research, 12, 97-107. 
Reichardt, W., Mcglone, M. S. \& Jacinto, G. S. (2007). Organic pollution and its impact on the microbiology of coastal marine environments: a Philippine perspective. Asian Journal of Water, Environment and Pollution, 4, 1-9.

Science for Environment Policy. (2015). Sustainable aquaculture. Future Brief 11. Brief produced for the European Commission DG Environment by the Science Communication Unit, UWE, Bristol, pp. 3-18. Retrieved from http:// ec.europa.eu/environment/integra tion/research/newsalert/pdf/sustain able_aquaculture_FB11_en.pdf.

Smith, V. H., Tilman, G. D. \& Nekola, J. C. (1999). Eutrophication: Impact of excess nutrient inputs on freshwater, marine, and terrestrial ecosystems. Environmental Pollution, 100, 179-196.

Smith, V. H., Joye, S. B. \& Howarth, R., W. (2006) Eutrophication of freshwater and marine ecosystems. Limnol. Oceanogr., 51, 351-355.
Tan, C., Ma, F., Li, A., Qui, S., \& Li, J. (2013). Evaluating the effect of dissolve oxygen on simultaneous nitrification and denitrification in polyurethane foam contact oxidation reactors. Water Environ. Res., 85 (3), 195-202. doi: 10.2175/1 $06143012 \times 13503213812445$

Tucker, C. \& Hargreaves, J. (2012). Ponds. In J. Tidwell (Ed), Aquaculture Production Systems (pp. 193-242). Iowa, USA: John Wiley and Sons.

United States - Environmental Protection Agency. (2009). Industrial waste resource guidelines: Sampling and analysis of waters, wastewaters, soils and wastes. Retrieved from http://www. epa.vic.gov.au/ /media/Publications/ IWRG701.pdf.

Vredenbregt, L.H.J., Nielsen, K., Potma, A.A., Kristensen, G.H., Sund, C., (1997). Fluid bed biological nitrification and denitrifi- cation in high sa linity wastewater. Water Sci. Technol. 36 (1), 93-100. 